\title{
Triglyceride-rich lipoproteins and high-density lipoprotein cholesterol in patients at high risk of cardiovascular disease: evidence and guidance for management
}

\section{John Chapman ${ }^{1 *}$, Henry N. Ginsberg ${ }^{2 *}$, Pierre Amarenco ${ }^{3}$, Felicita Andreotti ${ }^{4}$, Jan Borén ${ }^{5}$, Alberico L. Catapano ${ }^{6}$, Olivier S. Descamps ${ }^{7}$, Edward Fisher ${ }^{8}$, Petri T. Kovanen', Jan Albert Kuivenhoven ${ }^{10}$, Philippe Lesnik', Luis Masana ${ }^{11}$, Børge G. Nordestgaard ${ }^{12}$, Kausik K. Ray ${ }^{13}$, Zeljko Reiner ${ }^{14}$, Marja-Riitta Taskinen ${ }^{15}$, Lale Tokgözoglu ${ }^{16}$, Anne Tybjærg-Hansen ${ }^{17}$, and Gerald F. Watts ${ }^{18}$, for the European Atherosclerosis Society Consensus Panel}

${ }^{1}$ European Atherosclerosis Society, INSERM UMR-S939, Pitié-Salpetriere University Hospital, Paris 75651, France; ${ }^{2}$ Irving Institute for Clinical and Translational Research Columbia University, PH 10-305 630 West 168th Street, NewYork, NY 10032, USA; ${ }^{3}$ Bichat University Hospital, Paris, France; ${ }^{4}$ Catholic University Medical School, Rome, Italy; ${ }^{5}$ University of Gothenburg, Sweden; ${ }^{6}$ University of Milan, Italy; ${ }^{7}$ Hopital de Jolimont, Haine Saint-Paul, Belgium; ${ }^{8}$ New York University, New York, USA; ${ }^{9}$ Wihuri Research Institute, Helsinki, Finland; ${ }^{10}$ University of Amsterdam, The Netherlands; ${ }^{11}$ Universitat Rovira \& Virgili, Reus, Spain; ${ }^{12}$ Herlev Hospital, Copenhagen University Hospital, University of Copenhagen, Denmark; ${ }^{13}$ St George's University of London, London, UK; ${ }^{14}$ University Hospital Center Zagreb, Croatia; ${ }^{15}$ Biomedicum, Helsinki, Finland; ${ }^{16}$ Hacettepe University, Ankara, Turkey; ${ }^{17}$ Rigshospitalet, University of Copenhagen, Denmark; and ${ }^{18}$ University of Western Australia, Perth, Australia

Received 25 November 2010; revised 17 February 2011; accepted 21 March 2011; online publish-ahead-of-print 29 April 2011

Even at low-density lipoprotein cholesterol (LDL-C) goal, patients with cardiometabolic abnormalities remain at high risk of cardiovascular events. This paper aims (i) to critically appraise evidence for elevated levels of triglyceride-rich lipoproteins (TRLs) and low levels of highdensity lipoprotein cholesterol (HDL-C) as cardiovascular risk factors, and (ii) to advise on therapeutic strategies for management. Current evidence supports a causal association between elevated TRL and their remnants, low HDL-C, and cardiovascular risk. This interpretation is based on mechanistic and genetic studies for TRL and remnants, together with the epidemiological data suggestive of the association for circulating triglycerides and cardiovascular disease. For HDL, epidemiological, mechanistic, and clinical intervention data are consistent with the view that low HDL-C contributes to elevated cardiovascular risk; genetic evidence is unclear however, potentially reflecting the complexity of HDL metabolism. The Panel believes that therapeutic targeting of elevated triglycerides $(\geq 1.7 \mathrm{mmol} / \mathrm{L}$ or $150 \mathrm{mg} / \mathrm{dL})$, a marker of TRL and their remnants, and/or low HDL-C $(<1.0 \mathrm{mmol} / \mathrm{L}$ or $40 \mathrm{mg} / \mathrm{dL})$ may provide further benefit. The first step should be lifestyle interventions together with consideration of compliance with pharmacotherapy and secondary causes of dyslipidaemia. If inadequately corrected, adding niacin or a fibrate, or intensifying LDL-C lowering therapy may be considered. Treatment decisions regarding statin combination therapy should take into account relevant safety concerns, i.e. the risk of elevation of blood glucose, uric acid or liver enzymes with niacin, and myopathy, increased serum creatinine and cholelithiasis with fibrates. These recommendations will facilitate reduction in the substantial cardiovascular risk that persists in patients with cardiometabolic abnormalities at LDL-C goal.

Keywords

High-density lipoprotein cholesterol • Triglycerides • Triglyceride-rich lipoproteins • Remnants • Cholesterol • Atherogenic dyslipidaemia • Cardiovascular disease • Atherosclerosis • Guidelines

\footnotetext{
* Corresponding authors: Tel: +331 42177878, Fax: +31 1458281 98, Email: john.chapman@upmc.fr (M.J.C.); Tel: +1 2123059562 , Fax: +1 212 305 3213, Email: hng1@columbia.edu (H.N.G.)

Published on behalf of the European Society of Cardiology. All rights reserved. (C) The Author 2011. For permissions please email: journals.permissions@oup.com The online version of this article has been published under an open access model. Users are entitled to use, reproduce, disseminate, or display the open access version of this article for non-commercial purposes provided that the original authorship is properly and fully attributed; the Journal, Learned Society and Oxford University Press are attributed as the original place of publication with correct citation details given; if an article is subsequently reproduced or disseminated not in its entirety but only in part or as a derivative work this must be clearly indicated. For commercial re-use, please contact journals.permissions@oup.com.
} 


\section{Introduction and rationale}

Despite considerable improvements in medical care over the past 25 years, cardiovascular disease (CVD) remains a major public health challenge. In Europe, CVD is responsible for nearly $50 \%$ of all deaths and is the main cause of all disease burden, ${ }^{1}$ with management costs estimated at $€ 192$ billion annually. ${ }^{2}$ However, with the increasing incidence of obesity, metabolic syndrome, and type 2 diabetes mellitus (T2DM), ${ }^{3}$ this burden is projected to escalate dramatically. At a time when Europe, like other developed regions, is faced with the need to contain expenditure, urgent action is needed to address this critical problem.

Current best treatment including lifestyle intervention and pharmacotherapy aimed at lowering plasma concentrations of low-density-lipoprotein cholesterol (LDL-C), reducing blood pressure, and preventing thrombotic events fails to 'normalize' risk in people at high risk of CVD (i.e. SCORE $>5 \%$ for CVD death $^{4}$ or 10-year Framingham risk score $>20 \%$ for CVD events ${ }^{5}$ ). Individuals with acute coronary syndromes (ACS) are at very high risk of recurrent events: $\sim 10 \%$ occur within the first 6-12 months, ${ }^{6,7}$ and $\sim 20-30 \%$ within 2 years. ${ }^{8,9}$ As the risk of recurrent events in statin-treated coronary heart disease (CHD) patients increases incrementally with each additional feature of the metabolic syndrome, ${ }^{10}$ this implies that other $\mathrm{CV}$ risk factors beyond LDL-C may deserve attention. These risk factors may be modifiable, e.g. non-LDL-C dyslipidaemia, hypertension, and abdominal obesity, or non-modifiable, e.g. age and gender. Therapeutic interventions targeted to the former group clearly hold potential for reducing this high $\mathrm{CV}$ risk that persists even with optimal treatment of LDL-C.

Post hoc analyses of prospective trials in ACS and stable CHD patients reveal that elevated plasma levels of triglycerides and low plasma concentrations of high-density lipoprotein cholesterol (HDL-C) are intimately associated with this high risk, even at or below recommended LDL-C goals. ${ }^{11-14}$ Furthermore, in T2DM patients, the UKPDS identified HDL-C as the second most important coronary risk factor, after LDL-C. ${ }^{15}$ Despite these data, guidelines are inconsistent in their recommendations for proposed levels of HDL-C or triglycerides either for initiation of additional therapies or for targets for such treatments in patients at LDL-C goal. ${ }^{4,5,16-19}$

The aim of this paper is to critically appraise the current evidence relating to triglycerides and HDL-C as CV risk factors or markers and to consider therapeutic strategies for their management. The focus is on individuals with cardiometabolic risk, characterized by the clustering of central obesity, insulin resistance, dyslipidaemia, and hypertension, which together increase the risk of CVD and T2DM. ${ }^{18}$

The EAS Consensus Panel is well aware of uncertainties and controversies regarding triglycerides and HDL-C levels, both as risk markers or targets of therapy. Triglycerides are predominantly carried in fasting conditions in very low-density lipoproteins (VLDLs) and their remnants, and postprandially in chylomicrons and their remnants. The generic term 'triglyceride-rich lipoprotein remnants', therefore, relates to chylomicron and VLDL particles which have undergone dynamic remodelling in the plasma after secretion from the intestine (chylomicrons) or liver (VLDL) (Figure 1). This remodelling results in a spectrum of particles

Figure I Upon entry into the circulation, chylomicrons (containing apo B-48) produced by the small intestine, and VLDL (containing apo B-100) produced by the liver undergo LPL-mediated lipolysis mainly in peripheral tissues, notably adipose tissue and muscle. Intravascular remodelling of TRL equally involves the actions of lipid transfer proteins (CETP, PLTP) and additional lipases (HL and EL) with the formation of remnant particles. TRL remnants are typically enriched in cholesterol and apo E, but depleted in triglyceride; they are principally catabolized in the liver upon uptake through the LRP and LDL receptor pathways. TRL remnants can contribute either directly to plaque formation following penetration of the arterial wall at sites of enhanced endothelial permeability, ${ }^{21}$ or potentially indirectly following liberation of lipolytic products (such as FFA and lysolecithin) which may activate pro-inflammatory signalling pathways in endothelial cells. ${ }^{20,21}$ Abbreviations: apo, apolipoprotein; CETP, cholesteryl ester transfer protein; EL, endothelial lipase; FFA, free fatty acids; HL, hepatic lipase; LDL, low-density lipoprotein; LPL, lipoprotein lipase; LRP, lipoprotein receptor-related protein; PLTP, phospholipid transfer protein; TRL, triglyceride-rich lipoprotein; VLDL, very-low density lipoprotein. 
which are heterogeneous in size, hydrated density, and lipid and protein composition ${ }^{20}$ and include intermediate-density lipoprotein (IDL) particles. No single biochemical trait allows the differentiation of remnants from newly secreted chylomicrons, VLDL and IDL. $^{21}$ Thus, plasma triglyceride levels correspond essentially to the sum of the triglyceride content in nascent VLDL and their remnants in the fasting state, together with that in chylomicrons and their remnants in the postprandial state. Consequently, the Panel has used the generic term 'triglyceride-rich lipoprotein (TRL) remnants' as a surrogate for plasma levels of both newly secreted TRLs and their remnants, the latter predominating in the typical person with cardiometabolic risk. ${ }^{21}$ As discussed below, increasing evidence suggests that remodelled chylomicrons and VLDL are atherogenic, primarily as a result of their progressive enrichment with cholesterol and depletion of triglycerides in the plasma compartment. This process also results in progressive reduction in their size. The term 'TRL remnants' has been used to emphasize our focus on atherogenic lipoproteins themselves rather than their major lipids.

Similarly, the Panel understands that, despite epidemiologic data and evidence from some animal models ${ }^{22}$ implying a role for HDL as anti-atherogenic and vasculoprotective lipoproteins, the metabolic and functional pathways linking HDL-C levels and protection from CVD are poorly defined. The Panel also recognizes that HDL represent a highly dynamic pool of heterogenous particles. ${ }^{23}$ As HDL particles vary greatly in terms of lipid and protein composition, it was decided to focus on HDL-C as the marker of CVD risk.

\section{Lipid and lipoprotein metabolism}

Cholesterol, in both free and esterified forms, and triglycerides are the two main lipids in plasma. They are transported in lipoproteins, pseudomicellar lipid-protein complexes, in which the main apolipoproteins, apo B-100/48, apo A-I, apo A-II, apo E, and the apo Cs, are integral components. Apo $B$ is a component of all atherogenic lipoproteins (chylomicron remnants, VLDL and their remnants, IDL, lipoprotein(a) $[\mathrm{Lp}(\mathrm{a})]$ and $\mathrm{LDL})$, whereas apo A-I and apo A-II are components of HDL. The apo B-containing lipoproteins and the apo A-I/A-II lipoprotein classes are closely interrelated via several metabolic pathways (Figure 2). ${ }^{23-25}$

In dyslipidaemic patients with cardiometabolic risk, increased free fatty acid flux may represent a significant abnormality driving increased hepatic assembly and secretion of VLDL, IDL, and/or LDL particles, although other mechanisms are also implicated. ${ }^{26,27}$ Low plasma levels of HDL-apo A-I are associated with its increased

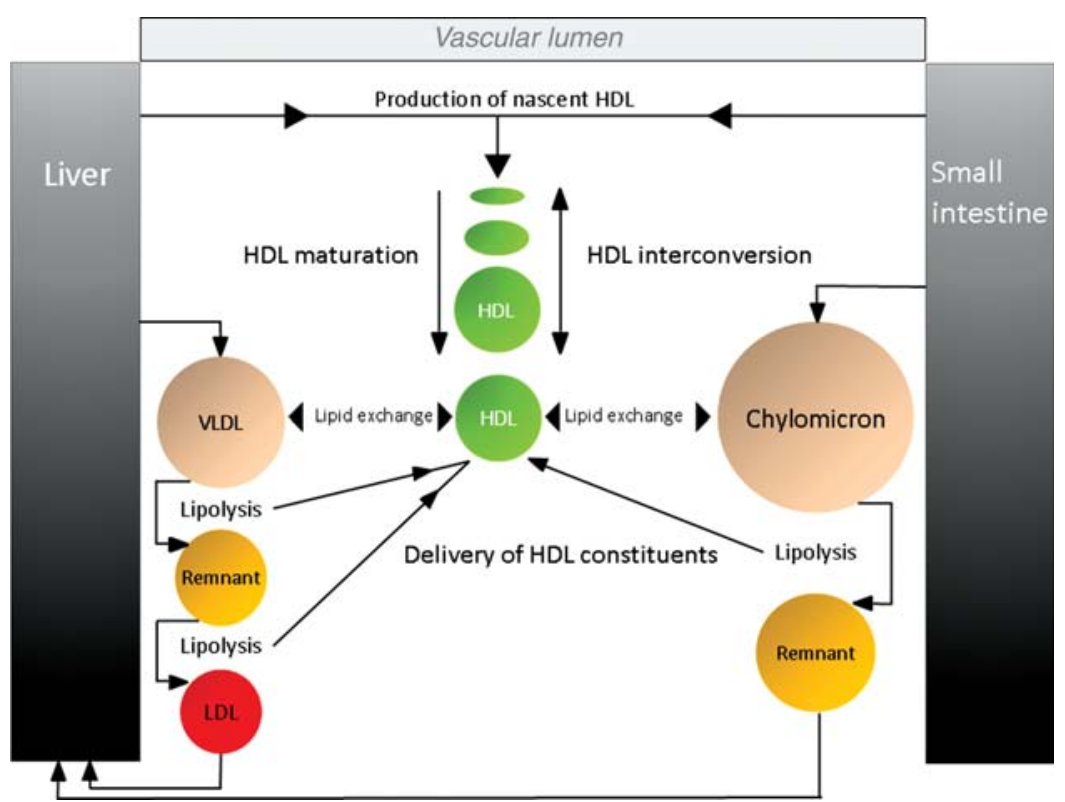

Figure 2 Metabolic pathways for HDL and triglyceride-rich lipoprotein remnants highlight their close interrelationship. De novo production of nascent HDL (discs) occurs in the liver and small intestine through the production of apo A-I (the major HDL protein) and lipidation (with cholesterol and phospholipids) of this protein by the ATP-binding cassette transporter (ABCA1) in these organs. Upon secretion, lecithin: cholesterol acyltransferase (LCAT) esterifies cholesterol on these discs which mature into spherical particles (due to the formation of a hydrophobic core resulting from generation of cholesteryl esters by LCAT). HDL undergoes extensive interconversion through triglyceride lipolysis (hepatic lipase, HL), phospholipid hydrolysis (endothelial lipase, EL), fusion (phospholipid transfer protein, PLTP), and lipid exchange among the HDL subpopulations (cholesteryl ester transfer protein, CETP). CETP also mediates major lipid transfer and exchange between HDL and triglyceride-rich lipoproteins (VLDL, chylomicrons) and their remnants [VLDL remnants = intermediate-density lipoproteins (IDLs), chylomicron remnants]. During this process, cholesteryl esters are transfered from HDL to VLDL and triglycrides move from VLDL to HDL. ${ }^{24} \mathrm{Chy}$ lomicrons also act as cholestery ester acceptors from LDL and HDL during the post-prandial phase. ${ }^{25} \mathrm{~A}$ second route that contributes to the plasma HDL pool involves hydrolysis of triglycerides in VLDL, IDL, and chylomicrons. In this process which is catalysed by lipoprotein lipase (LPL), phospholipids, as well as several apolipoproteins (such as apo $\mathrm{Cl}, \mathrm{Cll}, \mathrm{CIII}, \mathrm{AV}$ ) are transferred to HDL. PLTP contributes significantly to this remodelling process. 
fractional removal. ${ }^{26}$ This is driven by both cholesteryl ester transfer protein (CETP)-mediated heteroexchange of triglycerides from apo B lipoproteins with cholesteryl ester from apo A-I lipoproteins, and dissociation of apo A-I from triglyceride-enriched HDL with clearance via the kidney. ${ }^{26,28,29}$ Such metabolic perturbations are frequently associated with insulin resistance, which may in turn influence the activities of lipoprotein lipase (LPL), CETP and potentially, hepatic lipase $(\mathrm{HL})$, phospholipid transfer protein, and endothelial lipase. Within this large dyslipidaemic group, however, many patients do not exhibit insulin resistance but nonetheless display a mixed dyslipidaemia characterized by elevated levels of TRL and LDL. This lipid phenotype typically involves subnormal concentrations of HDL-C and increased cardiovascular risk. ${ }^{30}$ Finally, although there are close links, both pathophysiologic and genetic, between the dyslipidaemia of insulin resistance and the phenotype of familial combined hyperlipidaemia $(\mathrm{FCHL}),{ }^{31}$ some individuals with elevated levels of TRL remnants do not have insulin resistance or T2DM. ${ }^{30,32,33}$ Such individuals are at increased risk for premature CVD, although it is not clear if this risk is higher or lower than in those with the dyslipidaemia of insulin resistance and/or T2DM.

Pharmacological correction of hypertriglyceridaemia in T2DM does not usually normalize low apo A-I levels, which probably reflects the complex mechanisms involved. ${ }^{26,29}$ The complexity of HDL metabolism is clearly relevant when strategies to raise HDL-C are reviewed; indeed, HDL-C concentration is at most an indirect marker of the anti-atherogenic activities that are associated with this lipoprotein. ${ }^{28}$

\section{What is the experimental evidence that triglyceride-rich lipoprotein remnants and high-density lipoprotein play a role in the pathophysiology of atherothrombosis?}

The retention of cholesterol-rich lipoproteins within the subendothelial matrix of the arterial wall is a key initiator of atherosclerosis. ${ }^{34}$ Sites of endothelial dysfunction constitute preferential arterial locations for lipoprotein penetration, accumulation, and plaque formation. ${ }^{34}$ Although LDL is considered the main atherogenic cholesterol-rich particle, other apo B-containing lipoproteins (TRL, their remnants, and $L p(a)$ ) also contribute to intimal cholesterol deposition, particularly as they contain a similar number of cholesterol molecules per particle $(\sim 2000)$ as LDL. ${ }^{21,35}$ In contrast, HDLs were originally thought to readily enter the subendothelial space and then return to the circulation, ${ }^{36}$ although recent studies highlight the need to reconsider this notion. ${ }^{37}$

Experimental studies show that particle size is a key determinant. While large chylomicrons and VLDL fail to penetrate the arterial wall, their smaller remnants not only penetrate the arterial intima but may be bound and retained by connective tissue matrix. ${ }^{38,39}$ Accumulation of both chylomicron and VLDL remnants enriched in apo $E$ has been demonstrated in human and rabbit atherosclerotic plaques. ${ }^{20,39-41}$ Such particles, also referred to as ' $\beta$-VLDL', can be taken up directly by arterial macrophages with massive cholesterol loading and foam cell formation. ${ }^{42,43}$ Elevated levels of TRL remnants have also been linked to the progression of coronary artery disease ${ }^{44}$ and the presence of echolucent carotid artery plaques. ${ }^{45}$ Clearly, TRL remnant cholesterol can contribute directly to plaque formation and progression. ${ }^{20}$

Triglyceride-rich lipoprotein remnants may also drive atherogenesis via indirect mechanisms, particularly those involving binding and lipolysis at the artery wall. ${ }^{20}$ Such mechanisms provide a key link to accelerated atherogenesis in the postprandial phase. Acutely elevated TRL remnants occurring in this phase are associated with impaired vasodilation, ${ }^{46}$ upregulated pro-inflammatory cytokine production, ${ }^{47}$ and enhanced inflammatory response and monocyte activation. ${ }^{48-51}$ All of these mechanisms may underlie endothelial dysfunction. Moreover, TRL remnants are of relevance to plaque disruption and subsequent thrombus formation, key events in the onset of most ACS. $^{52,53}$ Triglyceride-rich lipoprotein remnants stimulate the secretion of tissue factor from endothelial cells and monocytes, ${ }^{54}$ and promote thrombin generation at levels similar to those caused by activated platelets. ${ }^{55}$ Elevated triglycerides are linked with raised concentrations of fibrinogen and coagulation factors VII and XII, and with impaired fibrinolysis as determined by enhanced gene expression and concentrations of plasminogen activator inhibitor-1. ${ }^{56,57}$

In contrast to TRL remnants, HDLs display a wide spectrum of biological activities (Box 1), of which cellular cholesterol efflux activity, and anti-inflammatory and anti-oxidative actions are key. ${ }^{23,28} \mathrm{HDLs}$ also contribute to pancreatic beta-cell function. ${ }^{5-60}$ The functionality of HDL is potentially highly vasculoprotective. HDLs maintain endothelial vasoreactivity, attenuate oxidative stress, inhibit endothelial cell apoptosis, contribute to the repair of damaged endothelium, ${ }^{61,62}$ inhibit monocyte activation, ${ }^{63}$ and reduce the expression of adhesion molecules and cytokines. ${ }^{28}$ Apo A-I may also immunoregulate lymphocytes and mononuclear cells. ${ }^{63,64}$ All of these actions may potentially attenuate component steps of atherosclerotic plaque formation. ${ }^{23,28,65}$

\section{Box $1 \mathrm{HDL}$ functionality: relevance to athero/vasculo-protection}

- Cellular cholesterol efflux and cholesterol homeostasis

- Regulation of glucose metabolism

- Anti-inflammatory activity

- Anti-oxidative activity

- Anti-apoptotic activity

- Endothelial repair

- Vasodilatory activity

- Anti-thrombotic activity

- Anti-protease activity

- Anti-infectious activity

To what degree can HDL counteract the prothrombogenic activity of TRL remnants, particularly since insulin-resistant states associate with thrombotic risk clustering? ${ }^{57} \mathrm{HDL}$ and apo A-I protect erythrocytes against the generation of procoagulant activity ${ }^{66}$ and augment the anticoagulant activity of protein $\mathrm{S}$. The latter enhances the function of activated protein $\mathrm{C}$, a critical factor in regulating 
blood coagulation by proteolytic inactivation of factors $\mathrm{Va}$ and VIIla. ${ }^{67} \mathrm{HDL}$ also affect platelet aggregation, inhibiting thrombin-induced binding of fibrinogen to platelets. ${ }^{68}$ Finally, in T2DM, in which HDL anti-atherogenic function is defective, ${ }^{28}$ infusion of reconstituted $(r) \mathrm{HDL}$ increases the anti-inflammatory and in vitro cholesterol efflux potential of $\mathrm{HDL}^{69}$ and reduces platelet hyperreactivity by lowering the cholesterol content of platelet membranes. ${ }^{70}$ Considered together, these data suggest a unifying hypothesis for the anti-atherothrombogenic actions of $\mathrm{HDL}$ and point to a crucial role in cellular cholesterol homeostasis. Significantly, HDL-mediated cholesterol efflux activity from macrophages was recently shown to be relevant both to carotid-intima thickness and coronary artery disease. ${ }^{71}$

A critical question is whether HDL impact long-term CV risk via these effects on the atherosclerotic process. The data from animal models have shown that overexpression of the human apo A-I gene increases HDL-C levels, protecting against diet-induced atherosclerosis. ${ }^{72}$ In addition, infusion of HDL or apo A-I Milano/phospholipid complexes reduced aortic lipid deposition and induced regression of atherosclerosis in rabbits. ${ }^{73,74}$ In humans, infusion of synthetic $\mathrm{rHDL}$ restored endothelial function in hypercholesterolaemic patients. ${ }^{75}$ Infusion of recombinant apo A-I Milano/phospholipid complexes reduced coronary atherosclerosis in ACS patients, although there was no dose-dependent effect. ${ }^{76}$ More recently, rHDL infusion reduced atheroma volume in subjects with premature coronary ${ }^{77}$ or peripheral atherosclerosis. ${ }^{78}$ Observational data from four intravascular ultrasound trials (two with statins) showed that lowering plasma apo B lipoprotein concentrations together with simultaneous minor elevation of HDL-C levels achieved plaque regression and stabilization. ${ }^{79}$ All of these findings urgently require confirmation in larger randomized studies.

Thus, in summary, the data indicate that TRL remnants and HDL are relevant throughout all stages of atherothrombosis, especially within the context of the insulin resistance syndrome. ${ }^{57}$

\section{Prevalence of elevated triglyceride-rich lipoprotein remnants and low high-density lipoprotein cholesterol}

First, it is important to ascertain the prevalence of atherogenic dyslipidaemia, i.e. the combination of elevated TRL remnants and/ or low HDL-C. ${ }^{80}$ Among the general population plasma concentrations of total cholesterol, LDL-C and HDL-C are normally distributed. In contrast, the distributions of triglycerides, remnant cholesterol, apo B, and non-HDL-C (i.e. total cholesterol-HDL-C) tend to be skewed with a tail toward the highest levels. In the Copenhagen General Population Study, low HDL-C levels were frequently associated with elevated levels of cholesterol and TRL remnants (Figure 3). Approximately $45 \%$ of men and $30 \%$ of women in the study had triglycerides $\geq 1.7 \mathrm{mmol} / \mathrm{L}(150 \mathrm{mg} / \mathrm{dL})$ with or without HDL-C $<1.0 \mathrm{mmol} / \mathrm{L}$ (40 mg/dL) (BG Nordestgaard, unpublished results). HDL-C levels are lower in Turkish populations, largely due to genetic predisposition. ${ }^{81,82}$ The Turkish Heart Study reported that $\sim 50 \%$ of men and $\sim 25 \%$ of women had HDL-C levels $\leq 0.9 \mathrm{mmol} / \mathrm{L}(35 \mathrm{mg} / \mathrm{dL}){ }^{82}$ As in other countries, atherogenic dyslipidaemia is on the rise, due to the increasing prevalence of the metabolic syndrome. In the Turkish Adults Risk Factor Study, 40\% of men and $35 \%$ of women had triglycerides $>1.7 \mathrm{mmol} / \mathrm{L}$ with or without low HDL-C ( $\leq 0.9 \mathrm{mmol} / \mathrm{L}$ or $35 \mathrm{mg} / \mathrm{dL}) .^{83}$

Atherogenic dyslipidaemia is more prevalent in individuals at high risk of CVD. In the Swedish National diabetes register including $>75000$ T2DM subjects, $37-38 \%$ had untreated hypertriglyceridaemia ( $>1.7$ and $\leq 4.0 \mathrm{mmol} / \mathrm{L}$, i.e. $>150$ and $\leq 354 \mathrm{mg} / \mathrm{dL}$ ) with or without low HDL-C. ${ }^{84}$ More than one-third of the CHD patients in EUROASPIRE III had elevated triglycerides ( $\geq 1.7 \mathrm{mmol} / \mathrm{L}$ or $150 \mathrm{mg} / \mathrm{dL}$ ) and/or low HDL-C; $\sim 50 \%$ of patients from Turkey had low HDL-C. ${ }^{85}$ In the PROCAM study,

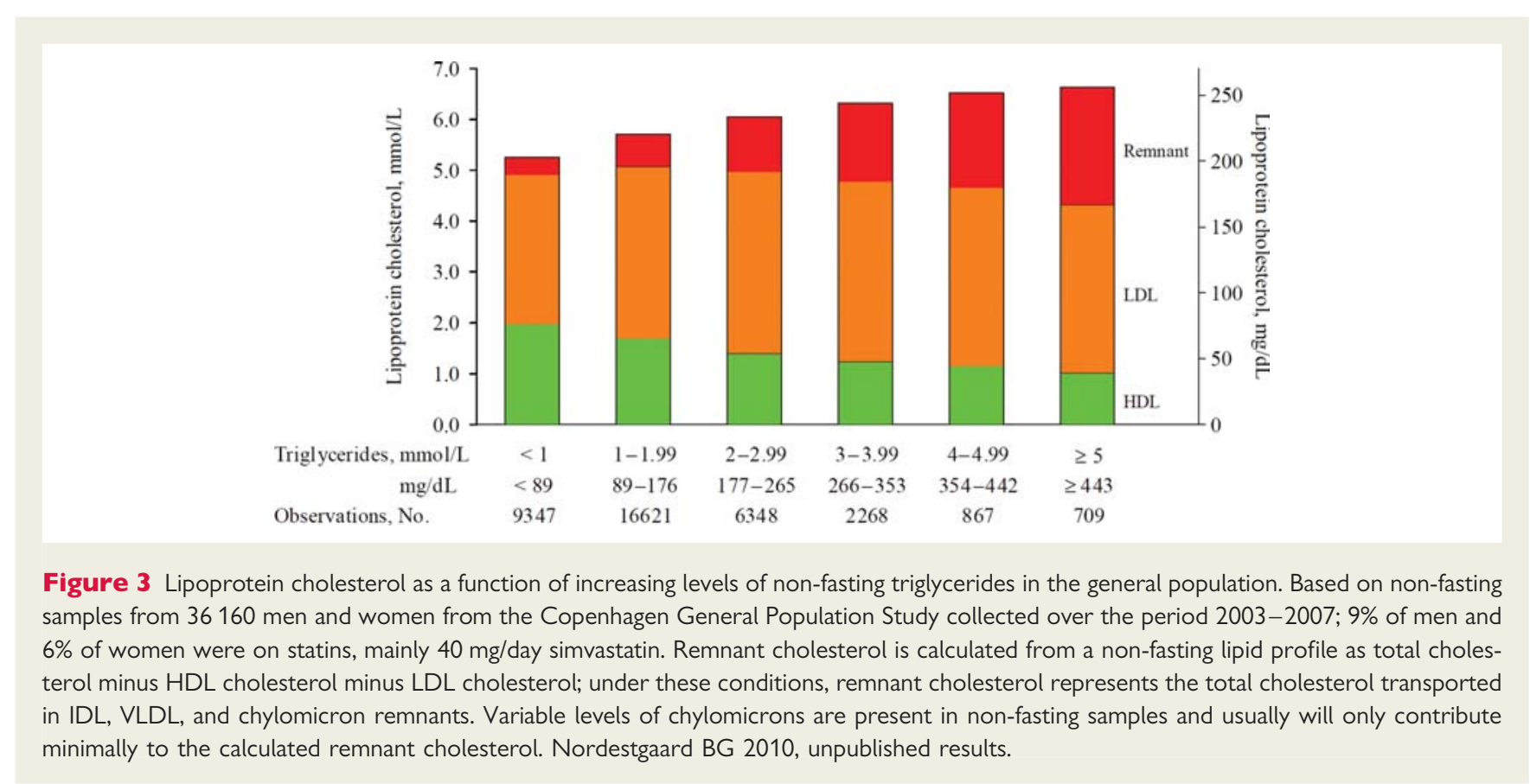


about twice as many myocardial infarction (MI) survivors had elevated triglycerides $(\geq 2.28 \mathrm{mmol} / \mathrm{L}$ or $200 \mathrm{mg} / \mathrm{dL}$ ) and/or low HDL-C $(<1.05 \mathrm{mmol} / \mathrm{L}$ or $40 \mathrm{mg} / \mathrm{dL})$ vs. matched controls; CV risk associated with this dyslipidaemic profile was higher also at low LDL-C levels. ${ }^{86}$ Together, these observational data highlight an unmet clinical need for treatment beyond LDL-C lowering in patients at high risk of CVD with atherogenic dyslipidaemia.

\section{What is the evidence that triglyceride-rich lipoprotein remnants and high-density lipoprotein cholesterol contribute to cardiovascular risk?}

The data from epidemiological and genetic studies are relevant to this question.

\section{Epidemiology \\ General populations}

Large observational studies clearly show that both elevated triglycerides (either fasting or non-fasting) ${ }^{87-90}$ and reduced plasma levels of HDL-C $\mathrm{C}^{91-93}$ are associated with increased CV risk. Scepticism of the role of elevated levels of TRL remnants in atherosclerosis and CVD has persisted despite the observation that patients with dysbetalipoproteinaemia (remnant hyperlipidaemia) with accumulation of apo $E$ and cholesterol-rich remnants typically display premature atherosclerosis and high CVD risk. ${ }^{94}$ Some suggested that individuals with lifelong, extremely high triglycerides $(25-300 \mathrm{mmol} / \mathrm{L}$ or $2200-26550 \mathrm{mg} / \mathrm{dL}$ ) and familial chylomicronaemia (e.g. due to LPL deficiency) did not present with accelerated atherosclerosis. ${ }^{94}$ Others observed the opposite, ${ }^{95}$ consistent with experimental data in animal models. ${ }^{96,97}$ However, the rarity of this disease prevents firm conclusions to be made.

The Emerging Risk Factors Collaboration (ERFC) ${ }^{93}$ provides the most robust evidence for the association of HDL-C with $\mathrm{CV}$ risk (Figure 4). This analysis of 68 studies in 302430 participants without prior history of CVD used individual participant data, allowing for harmonization and consistent adjustment of confounding factors, hitherto unfeasible. HDL-C was strongly associated with coronary risk even after adjustment for non-HDL-C and log triglycerides and non-lipid risk factors. Each unit of standard deviation (SD) increase in HDL-C concentration $(0.38 \mathrm{mmol} / \mathrm{L}$ or $15 \mathrm{mg} / \mathrm{dL}$ ) was associated with $22 \%$ reduction in CHD risk. Importantly, this protective effect was equal across the range of triglyceride levels. However, it is acknowledged that the data are not clear for HDL-C levels $<0.5$ or $>2.2-2.5 \mathrm{mmol} / \mathrm{L}(<19 \mathrm{mg} / \mathrm{dL}$ or $>85-$ $100 \mathrm{mg} / \mathrm{dL}$ ). Non-HDL-C and apo B each had very similar associations with $\mathrm{CHD}$. Both HDL-C and non-HDL-C were also modestly associated with ischaemic stroke (Figure 4), but not haemorrhagic stroke.

While coronary risk was increased by $37 \%$ (95\% Cl $31-42 \%)$ per SD increase in $\log _{\mathrm{e}}$ triglycerides, this association was weakened after adjustment for HDL-C and abrogated after correction for non-HDL-C. Additionally, triglycerides were not associated with stroke risk after adjustment for other lipid factors. ${ }^{93}$ These data are compatible with the view that it is the number of TRL and remnant particles that cause CVD. Thus, the risk associated with elevated triglycerides can be explained by this lipid acting as a marker for increased numbers of TRL, which in turn are closely associated with the combination of higher levels of non-HDL-C and low levels of HDL-C. In the Copenhagen City Heart Study, increased risk for $\mathrm{MI}$, ischaemic stroke, and mortality was evident at markedly elevated triglycerides $(>5.0 \mathrm{mmol} / \mathrm{L}$ or $>450 \mathrm{mg} / \mathrm{dL}$ ), although these data were not adjusted for non-HDL-C (Figure 5). ${ }^{89,90}$ Thus, low HDL-C and elevated non-HDL-C and triglycerides appear to be relevant to $\mathrm{CV}$ risk beyond LDL-C.

\section{Clinical trial populations}

Epidemiological evidence for low HDL-C as a major, independent $\mathrm{CV}$ risk factor is strengthened when considering clinical trial data in high-risk statin-treated patients (Table 1). ${ }^{12,98-100}$ In the TNT study, low on-treatment HDL-C concentration was a significant predictor for coronary events at low LDL-C $(<1.8 \mathrm{mmol} / \mathrm{L}$ or $70 \mathrm{mg} / \mathrm{dL})$, even after adjustment for $\mathrm{CV}$ risk factors, including on-treatment LDL-C and triglycerides and baseline HDL-C. ${ }^{12}$ A meta-regression analysis questioned the relevance of HDL-C to CV risk, although methodological issues may limit its validity ${ }^{101}$ [the analysis included 299310 participants at risk of CV events in 108 studies of any lipidmodifying agent (either as monotherapy or in combination) or diet/ surgery with a minimum of 6 months follow-up. There were no significant associations between the treatment-induced change in HDL-C and risk ratios for CHD events, CHD death, or total mortality after adjustment for changes in LDL-C. However, there are a number of important methodological issues with this analysis including: (i) the use of aggregated data rather than individual subject data; (ii) the method of analysis which describes an observational association and therefore risks bias by confounding; (iii) the combination of treatments and diets with important differences in pharmacology or mechanism of action; and (iv) failure to take account of the effect of baseline lipid profile which is known to influence the extent of HDL-C-raising]. Recently, a meta-analysis of 170000 subjects in 26 statin trials (24 332 CVD events) showed that irrespective of the achieved LDL-C level or the intensity of statin therapy, CV risk was always lower at higher levels of achieved HDL-C, with no attenuation of this relationship at low LDL-C levels. The lowest risk was observed in those with both a low LDL-C and a high HDL-C. ${ }^{100}$ This largely refutes suggestions that HDL-C concentration may be less predictive at very low LDL-C levels as in the JUPITER trial (393 CV events). ${ }^{102}$

While the $4 \mathrm{~S}$ trial showed no association between on-treatment levels and changes from baseline levels for triglycerides and reduction in $\mathrm{CV}$ risk, ${ }^{103}$ data from more recent trials are indicative of association. ${ }^{11,104,105}$ In the PROVE IT-TIMI 22 trial, on-treatment triglycerides $<1.7 \mathrm{mmol} / \mathrm{L}(<150 \mathrm{mg} / \mathrm{dL})$ were independently associated with a lower risk of recurrent coronary events in ACS patients at LDL-C goal $(<1.8 \mathrm{mmol} / \mathrm{L}$ or $70 \mathrm{mg} / \mathrm{dL}){ }^{11}$ Further, pooled analysis of the TNT and IDEAL trials showed a trend for decreased $C V$ event risk with lowering of triglycerides $(P<0.001)$, although this was attenuated by adjustment for HDL-C and the ratio of apo B/apo A-I. ${ }^{104}$

In T2DM patients, the FIELD and ACCORD Lipid studies showed that marked atherogenic dyslipidaemia (triglycerides $\geq 2.3 \mathrm{mmol} / \mathrm{L}$ or $204 \mathrm{mg} / \mathrm{dL}$ and low HDL-C levels $(\leq 0.88 \mathrm{mmol} / \mathrm{L}$ or $34 \mathrm{mg} / \mathrm{dL}$ 

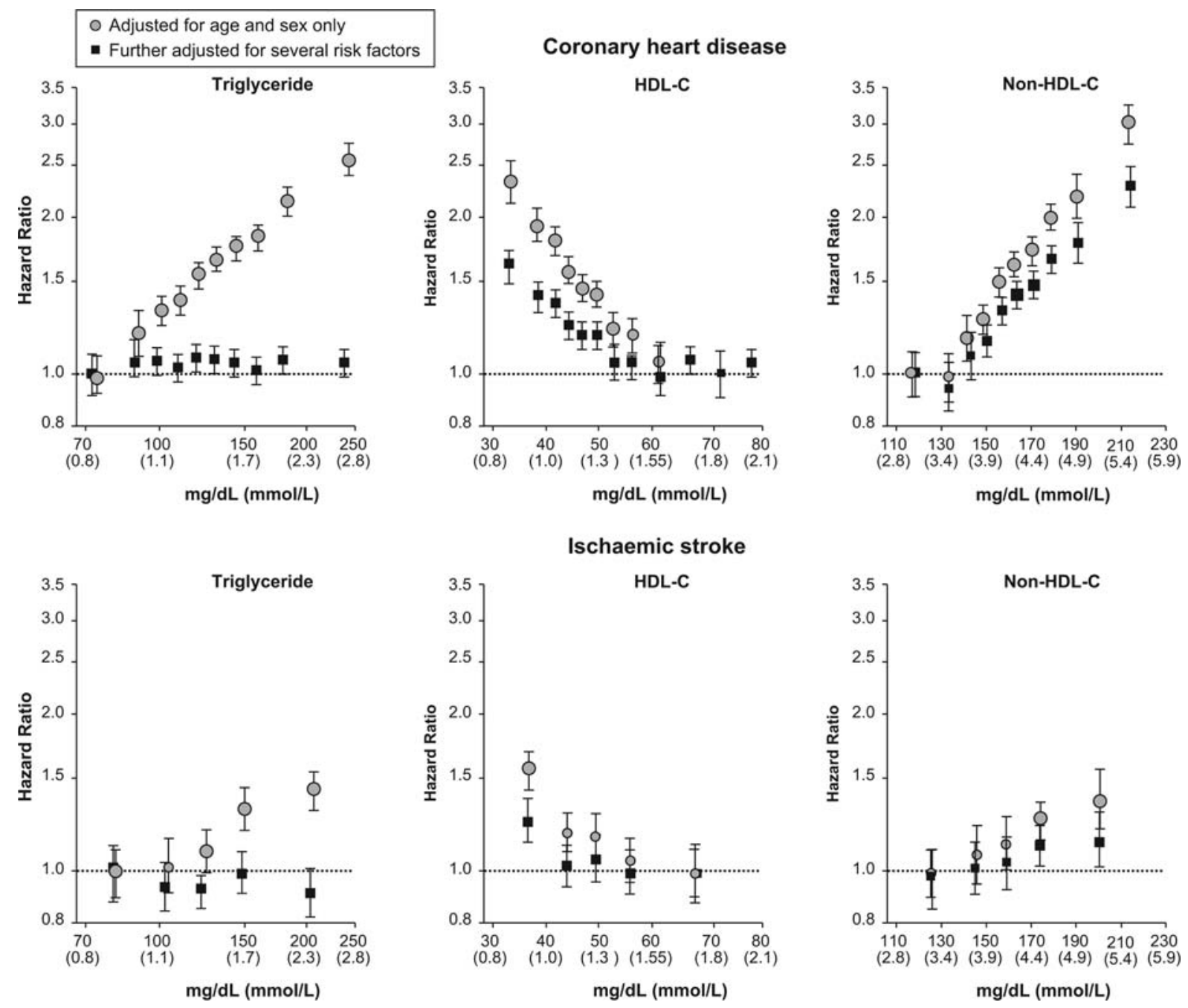

Figure 4 Hazard ratios for coronary heart disease and ischaemic stroke across quantiles of usual concentrations of triglycerides, HDL, and non-HDL cholesterol levels. Reproduced with permission from the Emerging Risk Factors Collaboration. ${ }^{93}$ CopyrightC) (2009) American Medical Association. All rights reserved.

in ACCORD Lipid) was associated with increased CV event rates (by $\sim 30-70 \%$ vs. those without this profile). ${ }^{106,107}$ Analyses from FIELD show that the hazard ratios for HDL-C, apo $A-I$, apo $B$, and non-HDL-C were comparable for the prediction of $C V$ risk whereas that for serum triglycerides was attenuated by adjustment for HDL-C $(P=0.07),{ }^{108}$ concordant with the ERFC analysis.

Taken together, these observational and clinical trial data support the view that (i) a low HDL-C concentration is associated with CVD independent of LDL-C (or non-HDL-C) levels, and (ii) that elevated triglycerides are moderately associated with CVD, potentially largely through the number of TRL remnants. Thus, while LDL-C lowering remains the first priority, therapeutic targeting of low HDL-C and elevated TRL remnants may offer the possibility of incremental reduction in CV risk in high-risk populations.

\section{Genetic studies of triglyceride and high-density lipoprotein metabolism}

In contrast, genetic studies do not provide clear insights into $\mathrm{CV}$ risk associated with changes in plasma triglycerides and HDL-C levels. This is not unexpected as predictions based on epidemiological studies may be inappropriate tools to assess complex biological pathways, especially for HDL metabolism. Monogenic disorders of triglyceride metabolism (involving functional mutations in the LPL, APOCIII, APOAV, LMF1, and GPIHBP1 genes) and HDL metabolism (involving the APOAI, LCAT, ABCA1, LIPC, LIPG, CETP, and SCARB 1 genes) have so far failed to provide answers, ${ }^{109}$ probably due to the rarity of these disorders. On the other hand, there is unequivocal evidence for markedly accelerated atherosclerosis and CVD in dysbetalipoproteinaemia, a familial dyslipidaemia in which the critical defect is homozygosity for the receptor binding-defective form of apo E, i.e. apo E2/E2, ${ }^{94}$ resulting in 


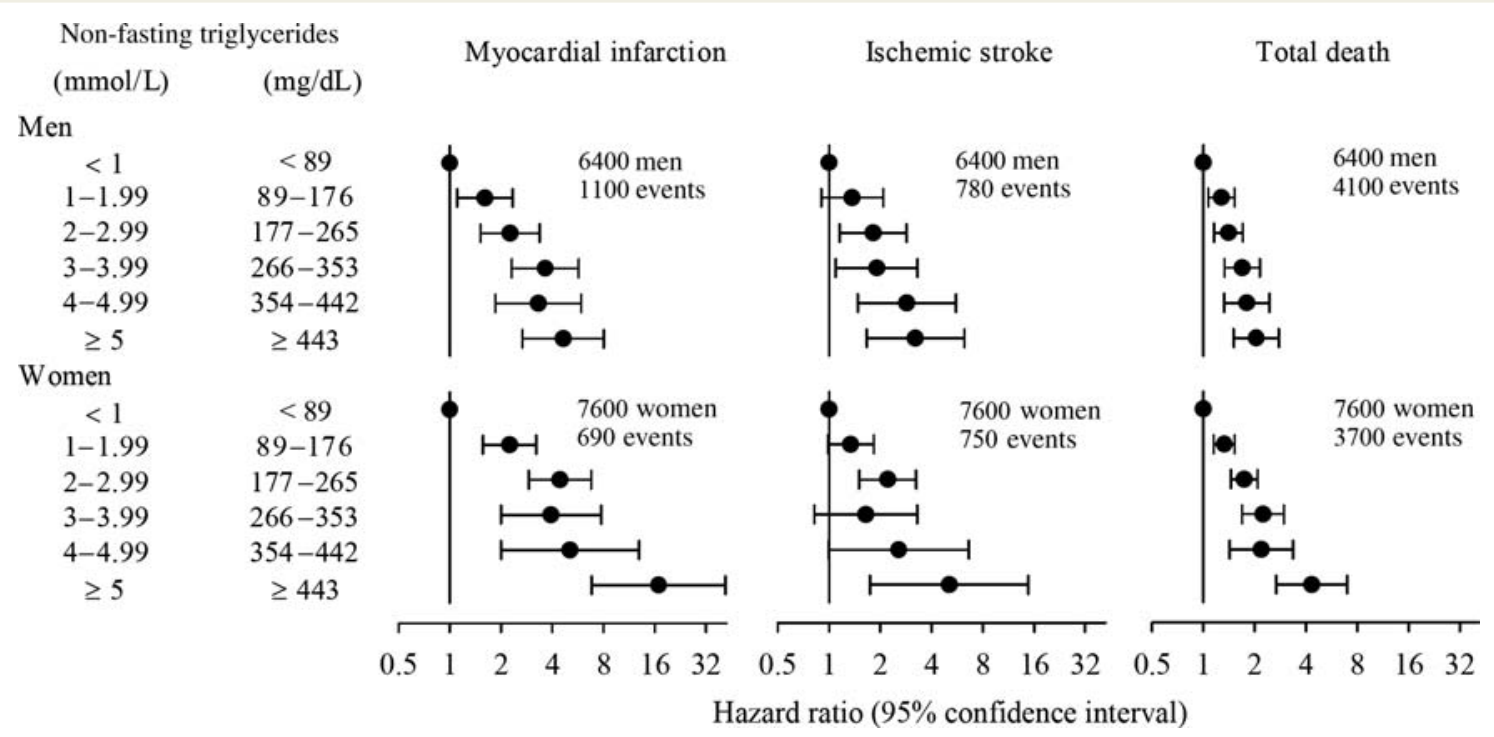

Figure 5 Relationship of non-fasting triglycerides (up to and $>5 \mathrm{mmol} / \mathrm{L}$ or $440 \mathrm{mg} / \mathrm{dL}$ ) and risk of myocardial infarction, ischaemic stroke, and total mortality. Results are shown as age-adjusted hazard ratios from the Copenhagen City Heart Study with 26-31 years of follow-up. Reproduced with modification from Nordestgaard et al. ${ }^{89}$ and Freiberg et al. ${ }^{90}$ Copyright () (2007, 2008) American Medical Association. All rights reserved.

Table I Overview of epidemiological evidence in community and clinical intervention populations supporting the association of low high-density lipoprotein cholesterol and/or elevated triglycerides with cardiovascular disease

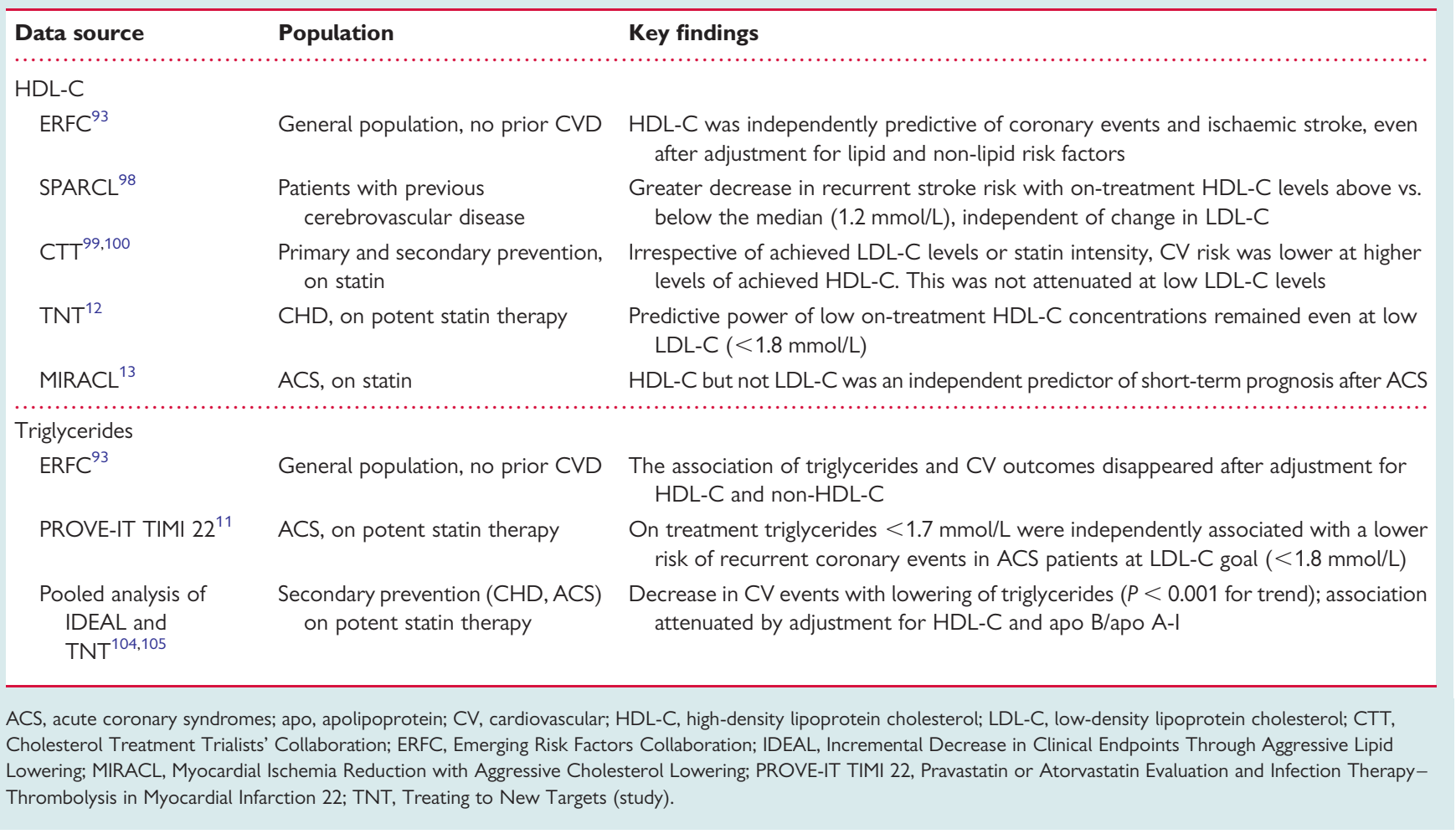

markedly elevated plasma levels of TRL remnants enriched in cholesterol and apo E.

Studies of frequent genetic coding variants and single-nucleotide polymorphisms (SNPs) in non-coding DNA (with no known direct functional significance), such as in the LPL gene, show an association between the combination of elevated triglycerides and low HDL-C and an increase in CV risk. ${ }^{110-114}$ In the initial genome-wide association studies (GWAS), variation at HDL loci was not associated with 
CVD risk; however, a recent meta-analysis identified four novel loci associated with CHD that were related to HDL-C or triglycerides (but not LDL-C), suggesting that pathways specifically relating to HDL or triglyceride metabolism may also modulate coronary risk. ${ }^{115}$ Collaborative analysis of a specific APOA5 variant $(-1131 T>C)$ that regulates triglycerides showed an association with coronary risk. The odds ratio for CHD $(1.18,95 \% \mathrm{Cl} 1.11-$ 1.26) per $C$ allele was also concordant with the hazard ratio (1.10, $95 \% \mathrm{Cl} 1.08-1.12)$ per $16 \%$ higher triglyceride concentrations in prospective studies, suggesting a causal association between triglyceride-mediated pathways (specifically high levels of remnant lipoproteins and low HDL-C) and CHD. ${ }^{116}$

Data for gene variants associated with isolated changes in plasma HDL-C levels are more conflicting. For example, increased plasma levels of HDL-C were correlated with increased $C V$ risk in individuals with SNPs in the LIPC gene associated with reduced $\mathrm{HL}$ activity. ${ }^{117-119}$ In contrast, genetic variants in ABCA1 associated with substantial reductions in HDL-C levels (with no changes in other lipids) were not associated with increased CV risk. ${ }^{120}$ On the other hand, three common CETP genotypes (TaqIB, 1405V, and $-629(>A)$ associated with lower CETP activity and higher HDL-C levels were inversely associated with coronary risk. ${ }^{114}$ In GWAS of genes known to impact HDL metabolism, the effects that such variants exert on HDL-C levels account for $<5 \%$ and frequently $<2 \%$ of variability. ${ }^{121,122}$ These data imply that in the general population, HDL-C concentration represents the integral sum of many gene effects on HDL metabolism. The current literature on the human genetics of HDL and TRL and their remnants highlights the need for clarification of the interaction between genes and different metabolic pathways, particularly for HDL.

\section{What is the clinical evidence that modulation of triglyceride-rich lipoprotein, their remnants, and high-density lipoprotein cholesterol impacts atherosclerosis and cardiovascular disease?}

\section{Lifestyle approaches}

Lifestyle interventions influence the metabolism of HDL and TRL remnants (Table 2). ${ }^{123-140}$ Smoking increases TRL remnants and decreases HDL-C levels, ${ }^{141}$ secondary to insulin resistance and hyperinsulinaemia; ${ }^{142}$ these effects are rapidly reversed on quitting. ${ }^{123}$ Aerobic exercise causes long-lasting reduction in triglycerides by up to $20 \%$ and increases in HDL-C by up to $10 \%$, although the same effects should not be assumed with progressive resistance training (Table 2). In T2DM subjects, intensive lifestyle intervention (weight loss, diet, and increased physical activity) had beneficial effects on glycaemic control and cardiometabolic risk factors, including HDL-C and triglycerides, ${ }^{143-145}$ and, in the longer term was associated with reduction in CVD risk. ${ }^{146}$ Other trials showed reduction in risk of progression to diabetes in people with impaired glucose tolerance, ${ }^{147,148}$ and improvement in other atherogenic processes including inflammation with physical activity. ${ }^{127}$
In CHD patients, lifestyle intervention trials have shown reduced progression of atherosclerosis, ${ }^{149-151}$ as well as reduction in the risk of CV events. ${ }^{152-154}$ Both the Diet and Reinfarction Trial ${ }^{153}$ and the Lyon Diet Heart Study ${ }^{154}$ showed substantial reduction in coronary events (by at least $50 \%$ ) with lifestyle intervention in $\mathrm{MI}$ survivors, but require replication to confirm these benefits. However, while a healthy lifestyle clearly is important in reducing CV risk, poor longterm adherence is a problem, and therefore many of these patients require additional pharmacological intervention.

\section{Clinical intervention studies}

Statin therapy alone, in addition to best standards of care, is unable to completely normalize CV risk associated with atherogenic dyslipidaemia. Higher doses may partially correct residual dyslipidaemia, but can also increase the risk of side effects, especially myopathy. Addition of ezetimibe or bile acid resins to statin therapy has little effect on triglycerides and HDL-C levels; resins may even raise triglycerides. Evidence is supportive of therapeutic approaches aimed at concomitantly lowering TRL and raising HDL-C to reduce $\mathrm{CV}$ risk. ${ }^{155}$ Of these options, both niacin and fibrates influence levels of multiple lipids and lipoproteins (Box $2^{35,156,157}$ ) and therefore clinically beneficial effects observed cannot be ascribed solely to changes in any single lipoprotein fraction. Pathways implicated in the lipid effects of niacin, fibrates, and omega- 3 fatty acids are summarized in Table 3. ${ }^{158-170}$

\section{Box 2 Lipid effects of niacin, fibrates and omega-3 fatty acids}

\begin{tabular}{|c|c|c|c|c|}
\hline & $\triangle \mathrm{LDL}-\mathrm{C}$ & $\triangle \mathrm{HDL}-\mathrm{C}$ & $\triangle T G$ & $\Delta L$ \\
\hline $\begin{array}{l}\text { Niacin } \\
(E R, 2 \text { g/day })\end{array}$ & $\downarrow 20 \%$ & $\begin{array}{l}\uparrow \text { up to } \\
30 \%^{\mathrm{a}}\end{array}$ & $\begin{array}{l}\downarrow \text { up to } \\
35 \%\end{array}$ & $\begin{array}{l}\downarrow \text { up } \\
30-\end{array}$ \\
\hline $\begin{array}{l}\text { - Effects are } \\
\text { dose-dependent }\end{array}$ & $\begin{array}{l}\uparrow \text { large } \\
\mathrm{LDL}\end{array}$ & $\begin{array}{l}\uparrow \text { large } \\
\mathrm{HDL}\end{array}$ & & \\
\hline $\begin{array}{l}\text { Fibrates } \\
\text { - Response } \\
\text { dependent on } \\
\text { baseline levels }{ }^{b}\end{array}$ & $\begin{array}{l}\text { Variable } \\
\uparrow \text { large } \\
\text { LDL }\end{array}$ & $\begin{array}{l}\uparrow \text { by } \\
5-20 \%^{c}\end{array}$ & $\begin{array}{l}\downarrow \text { by } \\
25-50 \%\end{array}$ & $\begin{array}{l}\text { No } \\
\text { effec }\end{array}$ \\
\hline $\begin{array}{l}\text { Omega-3 fatty } \\
\text { acids }\end{array}$ & $\begin{array}{l}\uparrow / \text { no } \\
\text { change }\end{array}$ & $\begin{array}{l}\uparrow / \text { no } \\
\text { change }\end{array}$ & $\begin{array}{l}\downarrow \text { by } \\
20-50 \%\end{array}$ & $\begin{array}{l}\text { No } \\
\text { effec }\end{array}$ \\
\hline
\end{tabular}

${ }^{a}$ Consistent HDL-C raising by up to $25 \%$ has been observed in patients with T2DM. bEffects depend on the individual fibrate, baseline lipid profile, and metabolic nature of dyslipidaemia.

${ }^{\text {c} A l t h o u g h ~ i n c r e a s e s ~ i n ~ H D L-C ~}$ with fibrates may be up to $20 \%$ in short-term studies, in long-term outcome studies in patients with T2DM the response to fenofibrate was much less ( $<5 \%$ at study close out), suggesting that fibrate treatment may be ineffective for raising HDL-C in this patient group.

\section{Niacin}

Niacin at therapeutic doses has a broad spectrum of effects on lipid and lipoprotein metabolism, including raising of HDL-C (Box 2). ${ }^{156}$ While various pathways are implicated, ${ }^{158-161}$ its mechanism of action is incompletely elucidated (Table 3). Niacin may also promote beneficial vasoprotective and anti-inflammatory effects independent of its lipid-modifying activity. ${ }^{171-173}$ 
Table 2 Effects of lifestyle interventions on plasma concentrations of HDL cholesterol and triglycerides

\begin{tabular}{|c|c|c|c|c|}
\hline Intervention & $\triangle$ HDL-C & Mechanism & $\triangle$ triglycerides & Mechanism \\
\hline Smoking cessation ${ }^{123}$ & $\uparrow 5-10 \%$ & $\begin{array}{l}\uparrow \text { LCAT and cholesterol } \\
\text { efflux; } \\
\downarrow \text { CETP }\end{array}$ & $\begin{array}{l}\text { No significant change } \\
\text { reported }\end{array}$ & - \\
\hline Weight loss $^{124}$ & $\begin{array}{l}\downarrow \text { during active weight loss } \\
\uparrow \text { after weight stabilization } \\
\text { by } 0.009 \mathrm{mmol} / \mathrm{L} \text { per } \mathrm{kg} \\
\text { weight lost }\end{array}$ & $\begin{array}{l}\uparrow \text { LCAT, LPL, } \\
\text { cholesterol efflux } \\
\downarrow \text { catabolism of } \\
\text { HDL, apo A-I }\end{array}$ & $\begin{array}{l}\downarrow \text { by } 0.015 \mathrm{mmol} / \mathrm{L} \\
\quad \text { per } \mathrm{kg} \text { weight loss }\end{array}$ & $\begin{array}{l}\uparrow \text { VLDL clearance } \\
\downarrow \text { hepatic VLDL secretion }\end{array}$ \\
\hline \multicolumn{5}{|l|}{ Exercise $^{125-131}$} \\
\hline Aerobic & $\begin{array}{l}\uparrow 5-10 \% \text { (moderate to } \\
\text { high intensity) }\end{array}$ & $\begin{array}{l}\uparrow \text { pre- } \beta \text { HDL, cholesterol } \\
\text { efflux, LPL } \\
\uparrow \text { in HDL size }\end{array}$ & $\begin{array}{l}\downarrow 10-20 \% \text { (moderate } \\
\quad \text { to high intensity) } \\
\downarrow \sim 30 \% \text { in VLDL-TG }\end{array}$ & $\begin{array}{l}\downarrow \text { hepatic VLDL-TG } \\
\text { secretion; } \\
\text { Beneficial adaptations in }\end{array}$ \\
\hline Resistance & $\begin{array}{l}\text { No significant } \\
\text { change reported }\end{array}$ & Improved HDL functionality & $\downarrow \sim 5 \%$ & $\begin{array}{l}\text { muscle fibre area, } \\
\text { capillary density, } \\
\text { glycogen synthase, and } \\
\text { GLTU4 protein } \\
\text { expression in T2DM or } \\
\text { impaired glucose } \\
\text { tolerance }\end{array}$ \\
\hline Alcohol $^{132-134}$ & $\uparrow 5-10 \%$ (1-3 drinks/day) & $\begin{array}{l}\uparrow \text { ABCA1, apo A-I } \\
\downarrow \text { CETP }\end{array}$ & $\begin{array}{l}\text { Variable response, } \\
\quad \uparrow \uparrow \text { in obese subjects } \\
\uparrow \uparrow \text { with excess intake }\end{array}$ & $\begin{array}{l}\uparrow \text { synthesis of VLDL-TG } \\
\text { with excess intake }\end{array}$ \\
\hline \multicolumn{5}{|l|}{ Dietary factors ${ }^{135-140}$} \\
\hline $\begin{array}{l}\text { n-3-PUFAs, } \\
\text { n-6-PUFAs, MUFAs }\end{array}$ & 0 to $\uparrow 5 \%$ & $\begin{array}{l}\text { Improves ratio of LDL-C/ } \\
\text { HDL-C } \\
\text { Improves HDL } \\
\text { anti-inflammatory activity }\end{array}$ & $\downarrow 10-15 \%$ & $\begin{array}{l}\uparrow \text { TG-rich lipoprotein } \\
\text { clearance via pathways } \\
\text { mediated by apo CIII and } \\
\text { apo E } \\
\downarrow \text { VLDL apo B secretion }\end{array}$ \\
\hline Omni-Heart & $\uparrow$ by $<5 \%$ & & $\begin{array}{l}\downarrow 56 \% \text { (increased protein) } \\
\downarrow 33 \% \text { (increased USFA) }\end{array}$ & \\
\hline
\end{tabular}

ABCA1, ATP-binding cassette transporter; apo, apolipoprotein; CETP, cholesteryl ester transfer protein; GLUT4, glucose transporter type 4; HDL, high-density lipoprotein; LCAT, lecithin:cholesterol acyltransferase; LDL, low-density lipoprotein; LPL, lipoprotein lipase; MUFA, monounsaturated fatty acids; PUFA, polyunsaturated fatty acids; TG, triglycerides; T2DM, type 2 diabetes mellitus; USFA, unsaturated fatty acids; VLDL, very low-density lipoprotein.

Imaging trials clearly document attenuated progression of atherosclerosis and intima-media thickening by niacin (Supplementary material online, Table S1)..$^{174-182}$ The only major outcome study to date, the Coronary Drug Project, showed that niacin (immediate-release $3 \mathrm{~g} /$ day) was associated with a $26 \%$ reduction in non-fatal $\mathrm{MI}(P<0.005)$ at $6-7$ years, and $11 \%$ reduction in allcause mortality $(P=0.0004)$ at 15 years $(\sim 9$ years after the end of treatment). ${ }^{183,184}$ These clinical benefits were similar in patients with or without hyperglycaemia, diabetes, or metabolic syndrome. ${ }^{185,186} \mathrm{~A}$ recent meta-analysis of niacin studies has confirmed these findings. ${ }^{187}$

Niacin may increase insulin resistance to a minor degree, although this may be potentially counterbalanced by recently documented protective effects of $\mathrm{HDL}$ on pancreatic beta cells. ${ }^{58,59}$ In the ADMIT and ADVENT studies in diabetic patients, potentially deleterious effects on glycaemia were effectively counteracted by adjusting anti-diabetic medication. ${ }^{188,189}$ However, the risk of new incident diabetes induced by niacin in insulin-resistant or pre-diabetic individuals remains indeterminate.
In patients with atherogenic dyslipidaemia, the combination of niacin plus statin improved the lipid-modifying efficacy of statin alone and was generally well-tolerated. ${ }^{190-192}$ Combination of niacin with laropiprant, an inhibitor of the prostaglandin $D_{2}$ receptor, ${ }^{193}$ significantly reduced but did not abolish flushing, the main tolerability issue. Among patients with T2DM, transient impairment of glucose control was reported (median increase in $\mathrm{HbA}_{1 \mathrm{C}} 0.3 \%$ over 12 weeks), ${ }^{194,195}$ consistent with known effects with niacin. ${ }^{188,189}$ Emerging evidence suggests that statin plus niacin can reduce progression of atherosclerosis in high-risk patients, including those with low LDL-C, as in the Oxford Niaspan trial ${ }^{182}$ (Supplementary material online, Table S1). There are limited data concerning the risk of myopathy with niacin-statin combination therapy. Definitive evidence regarding the longer-term risks of incident diabetes, myotoxicity, and hepatoxicity are awaited from the HPS2-THRIVE and AIM-HIGH trials (projected enrolment 25000 and 3300, respectively). Data from AIM-HIGH are expected in early 2013.

In summary (Box 3), evidence for the anti-atherosclerotic action of niacin is robust. ${ }^{156} \mathrm{~A}$ meta-analysis also suggests that adding niacin to 
Table 3 Mechanisms implicated in the lipid-modifying activity of niacin, fibrates and omega-3 fatty acids

\begin{tabular}{|c|c|}
\hline Drug & Proposed mechanisms \\
\hline Niacin ${ }^{156,158-161,166}$ & $\begin{array}{l}\text { Not clear. the following have been implicated: } \\
\downarrow \text { TG synthesis and hepatic secretion of VLDL } \\
\text { Possibly, direct inhibition of DGAT-2 } \\
\text { Partial inhibition of hormone sensitive TG lipase in adipose tissue } \\
\text { Up-regulation of apo A-I production } \\
\text { Possibly, delayed catabolism of larger HDL particles } \\
\text { Potential attenuation of CETP activity }\end{array}$ \\
\hline Fibrate ${ }^{156,162-166}$ & $\begin{array}{l}\text { Transcriptional regulation mediated via interaction with PPAR } \alpha \text {. Pathways involved include: } \\
\uparrow \text { catabolism of VLDL, IDL, and LDL apo B100 due to } \uparrow \text { LPL expression and activity } \\
\downarrow \text { production rate of apo CIII, thereby potentiating LPL activity (fenofibrate) } \\
\uparrow \text { VLDL apo B or VLDL-TG turnover (bezafibrate, gemfibrozil) } \\
\uparrow \text { production of apo A-II and lipoprotein Al:All although no change in lipoprotein A-I with fenofibrate } \\
\uparrow \mathrm{HDL}_{2 \mathrm{a}} / \mathrm{HDL} \mathrm{L}_{3 \mathrm{a}} \text {, linked to reduced CETP activity }\end{array}$ \\
\hline Omega-3 fatty acids ${ }^{138,157,167-170}$ & $\begin{array}{l}\text { Transcriptional regulation of SREBP-1c and PPAR } \alpha \\
\text { Inhibition of hormone-sensitive TG lipase and stimulation of LPL possibly through regulation of PPAR } \delta \\
\downarrow \text { TG secretion and and lipogenesis } \\
\uparrow \text { mitochondrial and peroxisomal fatty acid oxidation } \\
\text { Inhibition of DGAT-2 } \\
\downarrow \text { VLDL B secretion, specifically VLDL } 1 \\
\uparrow \text { conversion of VLDL to LDL } \\
\downarrow \text { catabolism of HDL apo A-I }\end{array}$ \\
\hline
\end{tabular}

apo, apolipoprotein; CETP, cholesteryl ester transfer protein; DGAT-2, diacylglycerol O-acyltransferase 2; IDL, intermediate-density lipoproteins; LPL, lipoprotein lipase; PPAR, peroxisome proliferator-activated receptor; SREBP, sterol regulatory element binding proteins; TG, triglycerides; VLDL, very low-density lipoproteins.

a statin may provide superior reduction in $\mathrm{CV}$ risk beyond that achieved with statin alone. ${ }^{187}$ The results of HPS2-THRIVE and AIM-HIGH will help discern whether niacin-statin therapy is effective across a wide spectrum of dyslipidaemic patients, or only in those with high triglycerides/low HDL-C dyslipidaemia.

\section{Box 3 Impact of niacin on atherosclerosis and clinical outcomes}

- Anti-atherosclerotic effects of niacin in combination with a statin have been extensively documented in plaque imaging studies in coronary and carotid arteries (see Supplementary material online, Table S1)

- Meta-analysis of niacin trials, several of which involved small patient numbers, is indicative of clinical benefit in patients with cardiometabolic disease ${ }^{187}$

- Ongoing trials (AIM-HIGH, HPS2-THRIVE) will evaluate whether ER niacin on top of statin therapy can reduce the CV risk that typically persists despite statin monotherapy in patients with atherogenic dyslipidemia and cardiometabolic disease

- HPS2-THRIVE, given the broad range of patients, will reveal whether niacin-statin therapy is effective across a wide spectrum of dyslipidaemic patients or only in those with high triglycerides/low HDL-C dyslipidaemia

\section{Fibrates}

Fibrates impact multiple pathways of lipid metabolism and may equally exert pleiotropic effects via regulation of genes influencing vascular inflammation and thrombogenesis. Their lipid-modifying effects (Box 2) are mediated primarily via interaction with peroxisome proliferator-activated receptor alpha (PPAR $\alpha$ ) (Table 3). ${ }^{156,162-166}$

Angiographic trials showed that fibrate therapy may attenuate atherosclerosis progression, ${ }^{196-198}$ although the impact on the progression of intima-media thickening has not been consistent ${ }^{199-201}$ (Supplementary material online, Table S2). Results from individual monotherapy outcomes trials have been variable and primarily indicate a reduction in nonfatal $\mathrm{Ml}$ and revascularization, with no effect on stroke or CV death, ${ }^{202-207}$ subsequently confirmed by a meta-analysis. ${ }^{208}$ Post hoc analyses of several of these trials provided consistent evidence suggestive of clinical benefit in the subgroup of patients with elevated triglycerides and low HDL-C (Table 4). ${ }^{106,206,209,210}$ Indeed, a recent meta-analysis confirmed enhanced benefit with fibrates in patients with atherogenic dyslipidaemia vs. those without. ${ }^{211}$ On the basis of such evidence, fibrate treatment appears appropriate in this subgroup (Box 4).

\section{Box 4 Statin-fibrate combination therapy: current status}

- Recent evidence from a meta-analysis suggests that fibrate therapy on a background of statin treatment provides clinical benefit in subgroups of patients with atherogenic dyslipidemia (Table 4)

- A large prospective trial to determine the long-term cardiovascular effects of a statin-fibrate combination in patients with the high triglyceride and low HDL-C phenotype is urgently needed 
Table 4 Subgroup analyses of cardiovascular outcome studies with fibrates

\begin{tabular}{|c|c|c|c|c|c|c|c|}
\hline \multirow[t]{2}{*}{ Trial } & \multirow{2}{*}{$\begin{array}{l}\text { Treatment } \\
\text { (mg/day) }\end{array}$} & \multirow[t]{2}{*}{ Patient characteristics } & \multicolumn{2}{|l|}{ All patients } & \multicolumn{3}{|c|}{ Elevated triglycerides and low HDL-C subgroup } \\
\hline & & & Primary endpoint & $\begin{array}{l}\text { Relative risk } \\
\text { reduction }\end{array}$ & $\begin{array}{l}\text { Primary } \\
\text { endpoint }\end{array}$ & $\begin{array}{l}\text { Lipid criteria } \\
\mathrm{mmol} / \mathrm{L}\end{array}$ & $\begin{array}{l}\text { Relative risk } \\
\text { reduction }\end{array}$ \\
\hline \multicolumn{8}{|c|}{ Fibrate monotherapy vs. placebo } \\
\hline $\begin{array}{l}\text { WHO } \text { trial }^{202} \\
\quad(n=5331)\end{array}$ & Clofibrate 1600 & $\begin{array}{l}\text { Upper-third of cholesterol } \\
\text { values, without } \mathrm{CHD}\end{array}$ & Non-fatal MI + CHD death & $20 \%(P<0.05)$ & - & - & - \\
\hline $\begin{array}{l}\mathrm{CDP}^{203} \\
\quad(n=3892)\end{array}$ & $\begin{array}{l}\text { Clofibrate } 1800 \\
\quad(n=1103)\end{array}$ & $\mathrm{CHD}$ & Nonfatal MI + CHD death & $9 \%(P=0.12)$ & - & - & - \\
\hline $\begin{array}{l}\mathrm{HHS}^{204,209} \\
\quad(n=4081)\end{array}$ & Gemfibrozil 1200 & $\begin{array}{l}\text { Non-HDL-C } \geq 200 \mathrm{mg} / \mathrm{dL} \\
\text { without } C H D\end{array}$ & Fatal + non-fatal MI + cardiac death & $34 \%(P<0.02)$ & As for all patients & $\begin{aligned} & \mathrm{TG}>2.3+ \\
& \mathrm{HDL}-\mathrm{C}<1.08\end{aligned}$ & $65 \%(P=0.01)$ \\
\hline $\begin{array}{l}\text { VA-HIT } \\
\qquad(n=205,210 \\
\qquad(n 31)\end{array}$ & Gemfibrozil 1200 & $\begin{array}{l}\mathrm{CHD}+\text { low HDL-C } \\
\quad(<40 \mathrm{mg} / \mathrm{dL})\end{array}$ & Non-fatal MI + CHD death & $22 \%(P=0.006)$ & As for all patients & $\begin{array}{l}\mathrm{TG}>2.03+ \\
\mathrm{HDL}-\mathrm{C} \leq 1.03\end{array}$ & $28 \%(P<0.05)$ \\
\hline $\begin{array}{l}\mathrm{BIP}^{206} \\
\quad(n=3090)\end{array}$ & Bezafibrate 400 & Previous $\mathrm{Ml}$ or angina & Fatal + non-fatal MI + sudden death & $9.4 \%(P=0.26)$ & As for all patients & $\begin{aligned} & \mathrm{TG} \geq 2.26+ \\
& \mathrm{HDL}-\mathrm{C}<0.91\end{aligned}$ & $42 \%(P=0.02)$ \\
\hline $\begin{array}{l}\text { FIELD }^{106,207} \\
\qquad(n=9795)\end{array}$ & Fenofibrate 200 & $\begin{array}{l}\text { Type } 2 \text { diabetes } \\
(22 \% \text { with } C V D)\end{array}$ & Non-fatal MI + CHD death & $11 \%(P=0.16)$ & Total CV events & $\begin{array}{l}\mathrm{TG} \geq 2.30+ \\
\quad \text { low HDL-C }\end{array}$ & $27 \%(P=0.005)$ \\
\hline \multicolumn{8}{|c|}{ Statin-fibrate vs. statin monotherapy } \\
\hline $\begin{array}{l}\text { ACCORD Lipid } \\
\quad(n=5518)\end{array}$ & $\begin{array}{r}\text { Fenofibrate } 160 \\
+ \text { simvastatin }\end{array}$ & $\begin{array}{l}\text { Type } 2 \text { diabetes } \\
(37 \% \text { with CVD) }\end{array}$ & $\begin{array}{l}\text { CVD death, nonfatal } \mathrm{MI}+\text { non-fatal } \\
\text { stroke }\end{array}$ & $8 \%(P=0.32)$ & As for all patients & $\begin{aligned} T G & \geq 2.30+ \\
H D L-C & \leq 0.88\end{aligned}$ & $\begin{array}{l}\text { 31\%; } P \text {-value not } \\
\text { reported }\end{array}$ \\
\hline
\end{tabular}

aln FIELD, low HDL-C was defined as $<1.03 \mathrm{mmol} / \mathrm{L}$ in men and $<1.29 \mathrm{mmol} / \mathrm{L}$ in women.

CHD, coronary heart disease; CV, cardiovascular; MI, myocardial infarction; WHO, World Health Organization.

ACCORD, Action to Control Cardiovascular Risk in Diabetes; BIP, Bezafibrate Infarction Prevention study; CDP, Coronary Drug Project; FIELD, Fenofibrate Intervention and Event Lowering in Diabetes study; HHS, Helsinki Heart Study; VA-HIT, Veterans Affairs HDL Intervention Trial. 


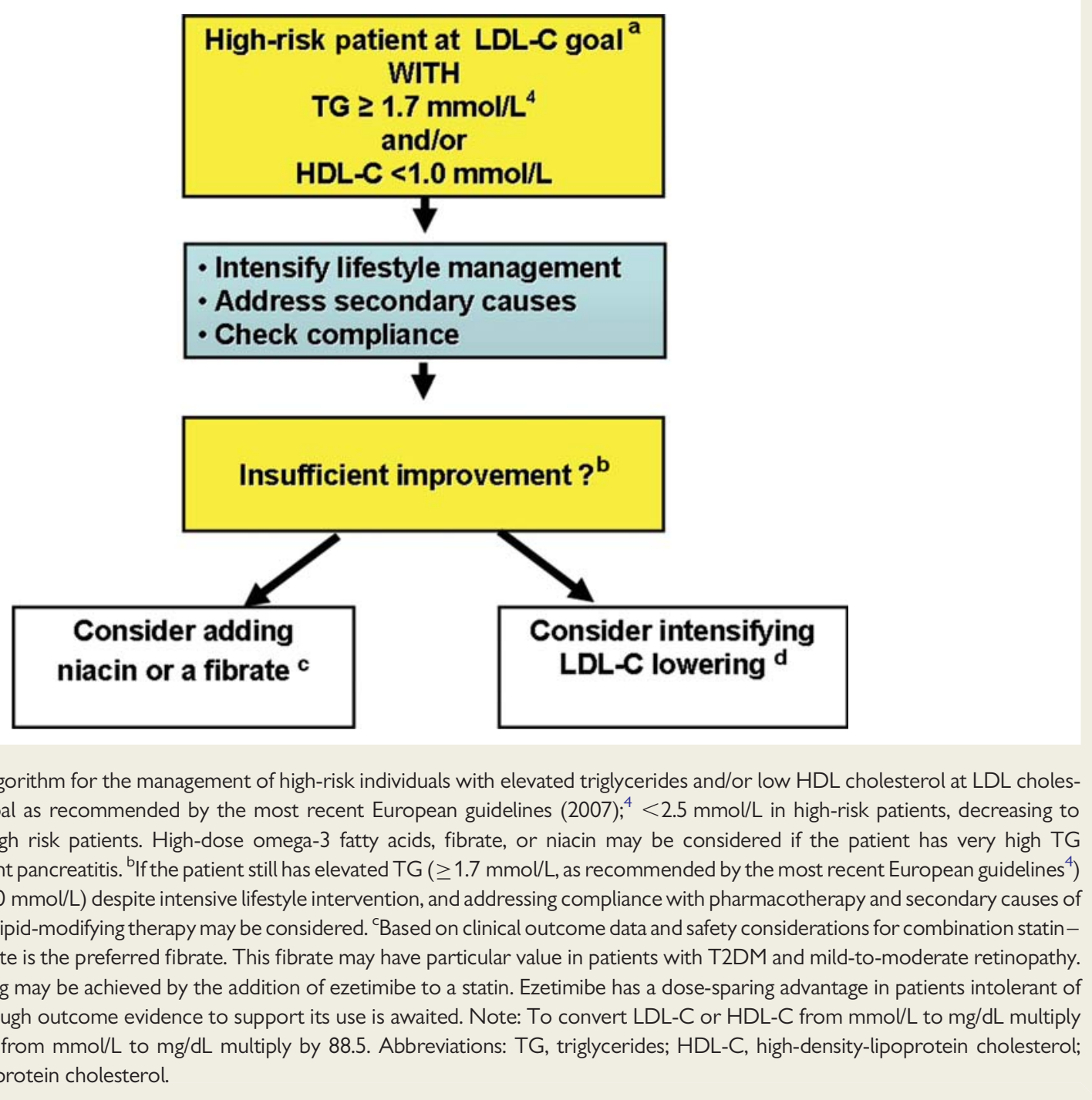

Combination of a statin with a fibrate (primarily fenofibrate) incrementally decreased plasma triglycerides by $15-20 \%$ and raised HDL-C by $5-20 \%$ vs. statin monotherapy. ${ }^{212-215}$ Similar effects were seen in FIELD and ACCORD Lipid, although the placebo-corrected increments in HDL-C in the total study cohorts were less than $3 \%{ }^{107,207}$ In ACCORD Lipid, the only completed outcome study of combination therapy, fenofibrate-simvastatin had no effect on the primary outcome vs. simvastatin alone for all patients. Importantly, however, in the fenofibrate-simvastatin group, there was a $31 \%$ reduction in CV risk in the subgroup with baseline triglycerides in the upper tertile $(\geq 2.3 \mathrm{mmol} / \mathrm{L}$ or $204 \mathrm{mg} / \mathrm{dL})$ and HDL-C levels in the lower tertile ( $\leq 0.88 \mathrm{mmol} / \mathrm{L}$ or $34 \mathrm{mg} / \mathrm{dL}$ ) vs. simvastatin monotherapy (Table 4). ${ }^{107}$ The available data also suggest that fenofibrate exerts microvascular benefits, notably in preventing progression of retinopathy in T2DM patients. ${ }^{216,217}$

Concerns about the safety of statin-fibrate combination therapy relate chiefly to the risk of myopathy, although this is substantially lower with fenofibrate than gemfibrozil. ${ }^{218}$ Current evidence based on ACCORD Lipid suggests that the incidence of myopathy with fenofibrate-statin combination therapy is similar to that with niacin-statin combination therapy. ${ }^{107,219}$ There were no reports of rhabdomyolysis with fenofibrate-statin combination therapy in either FIELD or ACCORD Lipid, ${ }^{107,207}$ and in ACCORD Lipid no increase in the incidence of venous thromboembolic disease, pancreatitis, or non-CV mortality. ${ }^{107}$ Fenofibrate increased serum creatinine and homocysteine (a rapidly reversible effect), ${ }^{107,220}$ and in the FIELD Helsinki cohort, decreased creatinine clearance and estimated glomerular filtration rate, with no effect on the urinary albumin creatinine ratio. ${ }^{221}$ Elevated serum homocysteine levels have been suggested as the basis for the neutral effect of fenofibrate on apo A-I. ${ }^{222}$ The clinical significance of these effects remains unclear. Finally, all fibrates are known to increase the long-term risk of cholelithiasis. ${ }^{218}$

In summary, statins firmly remain the first line treatment of choice for attainment of LDL-C goal in patients at high risk of CVD. ${ }^{4,5}$ After LDL-C goal attainment however, and if triglyceride levels remain elevated $(\geq 1.7 \mathrm{mmol} / \mathrm{L}$ or $150 \mathrm{mg} / \mathrm{dL}$, as defined by recent European guidelines $\left.{ }^{4}\right)$ and HDL-C low $(<1.0 \mathrm{mmol} / \mathrm{L}$ 
Table 5 Evidence supporting the contention that elevated LDL-C, elevated fasting or non-fasting TRL and their remnants, and subnormal HDL-C alone and/or together play causal roles in CVD

\begin{tabular}{|c|c|c|}
\hline Type of evidence & Elevated LDL-C & Elevated TRL, their remnants or low HDL-C \\
\hline Human epidemiology & $\begin{array}{l}\text { Direct association between } \\
\text { LDL-C and CVD in } \\
\text { numerous studies }\end{array}$ & $\begin{array}{l}\text { Direct association between TG and CVD in numerous studies; association lost on correction for } \\
\text { non-HDL-C and HDL-C in ERFC } \\
\text { Strong inverse association between low HDL-C and CVD in numerous studies; association } \\
\text { maintained after correction for TG and non-HDL-C in ERFC }\end{array}$ \\
\hline Mechanistic studies & $\begin{array}{l}\text { Definitive mechanistic } \\
\text { evidence; } L D L \text { accumulate } \\
\text { in arterial intima and } \\
\text { promote atherosclerosis }\end{array}$ & $\begin{array}{l}\text { Arterial accumulation of TRL and their remnants to promote atherosclerosis like LDL, with } \\
\text { potential pro-inflammatory and pro-thrombotic/anti-fibrinolytic effects } \\
\text { In vitro and ex vivo evidence for potential anti-inflammatory vasculoprotective, anti-thrombotic } \\
\text { and cytoprotective effects of HDL particles; central implication of cholesterol acceptor } \\
\text { activity }\end{array}$ \\
\hline Animal models & $\begin{array}{l}\text { Pro-atherogenic effect in } \\
\text { numerous studies }\end{array}$ & $\begin{array}{l}\text { Pro-atherogenic and pro-inflammatory effects for TRL and their remnants } \\
\text { Atheroprotection exerted by elevated } \mathrm{HDL} \text { or apo A-I levels }\end{array}$ \\
\hline $\begin{array}{l}\text { Human genetic } \\
\text { studies }\end{array}$ & $\begin{array}{l}\text { Direct causal association in } \\
\text { numerous studies, and } \\
\text { notably in familial } \\
\text { hypercholesterolaemia }\end{array}$ & $\begin{array}{l}\text { Dysbetalipoproteinaemia (remnant hyperlipidaemia , apo E2/E2) provides causal evidence for } \\
\text { the atherogenicity of elevated TRL and their remnants } \\
\text { Lack of definitive insight for HDL-C, potentially due to the complexity of HDL metabolism }\end{array}$ \\
\hline $\begin{array}{l}\text { Human intervention } \\
\text { studies }\end{array}$ & $\begin{array}{l}\text { Statin trials provided } \\
\text { conclusive proof of } \\
\text { causality }\end{array}$ & $\begin{array}{l}\text { Imaging trials reveal that fibrate therapy may impact atherosclerosis progression but fails to slow } \\
\text { intima-media thickening; see Supplementary material online, Table S2 } \\
\text { Meta-analysis of fibrate trials ( }+ \text { statin) show clinical benefit limited to non-fatal CV events. }{ }^{208} \\
\text { Subgroup analyses reveal major reduction in CV events in patients with high TG and low } \\
\text { HDL-C }{ }^{211} \\
\text { Niacin imaging trials showed consistent stabilization and/or regression of atherosclerosis or } \\
\text { intima-media thickening in monotherapy or in combination; see Supplementary material } \\
\text { online, Table S1 } \\
\text { Reduction in CV events and total mortality with niacin monotherapy }{ }^{183,184}\end{array}$ \\
\hline Interpretation $2010^{\mathrm{a}}$ & Definite causality & $\begin{array}{l}\text { Evidence suggestive of a strong causal association of atherogenic dyslipidaemia, i.e. elevated TRL } \\
\text { and their remnants combined with low HDL-C } \\
\text { Insufficient evidence for TRL and their remnants alone } \\
\text { Insufficient evidence for low HDL-C alone }\end{array}$ \\
\hline
\end{tabular}

${ }^{\text {a} F o r ~ a n ~ i n t e r p r e t a t i o n ~ o f ~ c a u s a l i t y ~ g i v e n ~ t h e ~ d a t a ~ a v a i l a b l e ~ i n ~ 2010, ~ a l l ~ f i v e ~ t y p e s ~ o f ~ e v i d e n c e ~ s h o u l d ~ f a v o u r ~ c a u s a l i t y ~ a n d ~ a l l ~ t h r e e ~ t y p e s ~ o f ~ h u m a n ~ s t u d i e s ~(e p i d e m i o l o g y, ~ g e n e t i c s, ~ a n d ~}$ intervention trials) must be consistent; this is clearly the case for elevated LDL-C.

or $40 \mathrm{mg} / \mathrm{dL}$ ) despite intensive lifestyle intervention, then addition of a fibrate or niacin may be considered (Figure 6).

\section{Omega-3 fatty acids}

Long chain omega-3 fatty acids [eicosapentaenoic acid (EPA) and docosahexaenoic acid (DHA) 2-4 g/day] are approved as an adjunct to diet for lowering plasma triglycerides when $>5.5 \mathrm{mmol} / \mathrm{L}(490 \mathrm{mg} / \mathrm{dL})$ to prevent pancreatitis. The profile of lipid-modifying activity is given in Box 2 and mechanisms involved are summarized in Table 3. ${ }^{138,157,167-170}$

Outcome benefits for omega- 3 fatty acids have been reported but relate to lower doses than required clinically to lower triglycerides (Supplementary material online, Table S3). ${ }^{223-225}$ These benefits may be explained by anti-arrhythmic effects, independent of triglycerides. ${ }^{226}$ The AFORRD trial in T2DM patients showed no benefit after 4 months of omega- 3 fatty acids ( 2 g/day) in combination with atorvastatin on estimated $\mathrm{CV}$ risk. ${ }^{227}$ Adverse effects are limited to minor dyspepsia, with no evidence of increased risk of significant bleeding, even with concomitant aspirin or warfarin.

\section{Future options}

HDL-C-raising per se may represent a key determinant of the clinical benefits associated with lipid-modifying therapy, ${ }^{228}$ although this concept still needs proof from randomized intervention trials.

CETP inhibitors increase HDL-C levels substantially, and some also affect LDL-C and triglyceride levels. ${ }^{166}$ Dalcetrapib (JTT-705) exerts moderate effects on plasma lipids (raising HDL-C by up to $37 \%$ ), ${ }^{229}$ whereas torcetrapib was far more potent (increases in HDL-C $>70 \%$ ), and modestly reduced LDL-C ( 20\%) and triglycerides (9\%). ${ }^{166}$ Despite this, the first outcome study with torcetrapib, ILLUMINATE, was prematurely terminated due to excess mortality. ${ }^{230}$ However, recent evidence $^{231,232}$ suggests that off-target pharmacological effects of torcetrapib were responsible for this adverse outcome rather than a class effect of CETP inhibitors. In all trials, torcetrapib treatment was associated with an increase in systolic blood pressure and electrolyte changes, mediated via hyperaldosteronism. Concerns that large HDL generated through CETP inhibition would be dysfunctional have not been supported by in vitro studies. ${ }^{233,234}$ Other CETP inhibitors (e.g. dalcetrapib and anacetrapib) do not show 
the off-target effects associated with torcetrapib, as indicated by recent studies. ${ }^{235,236}$ Clinical outcome data from ongoing or planned studies (dal-OUTCOMES with dalcetrapib and REVEAL with anacetrapib) are awaited.

\section{What is the evidence for a causal role of elevated triglyceride-rich lipoprotein and their remnants and/or low high-density lipoprotein cholesterol in premature atherosclerosis and cardiovascular disease?}

The EAS Consensus Panel considers that for an interpretation of causality, five types of evidence should each favour causality (Table 5) with consistent evidence required from all three types of clinical evidence (epidemiology, genetics, and intervention trials). ${ }^{237}$ For elevated LDL-C, the consensus is definite causality. The Panel contends, on the basis of available evidence, that elevated TRL and their remnants combined with low HDL-C may also play a causal role in premature atherosclerosis, whereas insufficient data are currently available for assessing the causality of TRL and remnants alone. The clinical relevance of isolated low HDL-C to CVD also remains unclear. ${ }^{238}$

\section{Guidance for clinical management}

The EAS Consensus Panel believes that targeting a high triglyceride/ low HDL-C phenotype is likely to be beneficial in patients with CVD or at high risk of CVD, especially those with cardiometabolic abnormalities. The therapeutic needs of these patients are likely to exceed LDL-C lowering by statin monotherapy. ${ }^{239}$ The recommended steps for managing these patients after achieving LDL-C goal, as defined by the most recent European guidelines, ${ }^{4}$ are summarized in Figure 6. The Panel proposes triglycerides as a marker for TRL and their remnants. Elevated triglycerides ( $\geq 1.7 \mathrm{mmol} / \mathrm{L}$ or $150 \mathrm{mg} / \mathrm{dL}$, consistent with European guidelines ${ }^{4}$ ) and/or low HDL-C $(<1.0 \mathrm{mmol} / \mathrm{L}$ or $40 \mathrm{mg} / \mathrm{dL})$ are triggers for considering further treatment in both men and women. HDL-C levels $<1.0 \mathrm{mmol} / \mathrm{L}(40 \mathrm{mg} / \mathrm{dL})$ in men and $<1.2 \mathrm{mmol} / \mathrm{L}(45 \mathrm{mg} / \mathrm{dL})$ in women are also considered a CV risk factor in current European guidelines. ${ }^{4}$ It is noteworthy that in ACCORD Lipid, a cutoff for triglycerides of $\geq 2.3 \mathrm{mmol} / \mathrm{L}$ identified statin-treated patients at high $\mathrm{CV}$ risk, who may respond to fibrates. ${ }^{107}$ For simplicity and convenience, measurement of non-fasting plasma lipids is recommended, supported by data from the ERFC, ${ }^{93}$ but care should be taken when interpreting triglyceride levels in individuals who have recently consumed a high-fat meal.

The Panel stresses that lifestyle modifications (Box 5) should underpin the management of all patients at increased $\mathrm{CV}$ risk, especially those with elevated triglycerides $(\geq 1.7 \mathrm{mmol} / \mathrm{L}$ or $150 \mathrm{mg} / \mathrm{dL})$ and/or low plasma levels of HDL-C ( $<1.0 \mathrm{mmol} / \mathrm{L}$ or $40 \mathrm{mg} / \mathrm{dL}$ ). As non-compliance can be a significant issue, addressing its causes and identifying solutions, including improvement in physician-patient alliance is essential. Secondary causes of dyslipidaemia, including poor glycaemic control, obesity, diets high in refined carbohydrates, alcohol excess, lack of exercise, and smoking must be addressed. Despite adherence to lifestyle interventions, it is likely that many of these patients with atherogenic dyslipidaemia will require pharmacotherapy. At least $50 \%$ of all high-risk patients on a statin may require optimization of treatment to further lower LDL-C, ${ }^{240}$ and about $10-15 \%{ }^{107}$ may need additional treatment for elevated triglycerides and/or low HDL-C. In these patients, clinicians may consider adding niacin or a fibrate, while taking into account potential safety issues, as discussed in this paper.

\section{Box 5 Recommended basic lifestyle interventions to lower triglycerides and increase HDL-C}

- Stop smoking: all smokers at high cardiovascular risk unable to quit smoking should be referred to specialized smoking cessation clinics

- Increase physical activity: aim for at least 30 min of moderate aerobic activity (activity producing a heart rate of $60-75 \%$ of age-related maximum heart rate) for at least 5 days per week

- Adopt a Mediterranean-type diet characterized by high monounsaturated and low saturated fatty acids, and lowcarbohydrate content. Avoid refined sugar and fructose rich diets which aggravate dyslipidaemia. Increase intake of complex carbohydrates, viscous fibre, and whole-grains

- Lose weight: obese and overweight subjects should adopt a calorie restriction diet, aiming to achieve optimal weight or at least to lose $10 \%$ of body weight

- Restrict alcohol intake to less than $30 \mathrm{~g}$ per day ( $<20 \mathrm{~g} /$ day in women). Avoid alcohol consumption in case of high triglyceride levels

In view of its broad spectrum lipid-modulating actions in atherogenic dyslipidaemia (Box 2), niacin may be of special value for reducing TRL and their remnants concomitant with raising HDL-C levels among patients with cardiometabolic abnormalities, particularly those with insulin resistance. However, definitive data from AIM-HIGH and HPS2-THRIVE are needed. Niacin is also unique in lowering Lp(a) levels. ${ }^{35}$ Treatment with niacin is supported by clinical evidence of stabilization or regression of atherosclerosis in clinical trials (see Niacin subsection). In practice, plasma glucose and urate levels should be monitored regularly for the possibility of hyperglycaemia and hyperuricaemia, respectively, and liver function tests should be monitored to exclude hepatotoxicity. In patients with impaired fasting glucose or impaired glucose tolerance, lifestyle modification is the first option to control glucose, and if niacin is introduced glucose levels should be monitored.

The current level of evidence for clinical outcomes benefits and safety suggests that fenofibrate may be the preferred fibrate for combination with a statin, and may also have particular value in T2DM patients with mild-to-moderate retinopathy. ${ }^{216,217}$ From a safety perspective, pre-treatment serum transaminases, creatine 
(phospho)kinase, and creatinine should be measured. Creatine (phospho)kinase should be repeated if myalgia is reported, or there are known risk factors for myopathy, and treatment discontinued if levels exceed five times the upper limit of normal and/or symptoms are severe. Alanine and aspartate transaminases should be monitored 3 months after starting therapy and annually thereafter, but more frequently if the dose of statin is uptitrated. Serum creatinine should be monitored with statin-fenofibrate combinations.

If patients are intolerant of both niacin and fenofibrate, a high dose of omega-3 fatty acids ethyl esters may be considered. In patients with very high triglycerides (>5.5 mmol/L or $490 \mathrm{mg} /$ $\mathrm{dL}$ ), fenofibrate, niacin, or high-dose omega-3 fatty acids (3-4 g/ day), together with a very low fat diet ( $<10 \%$ of calorie intake) and reduced alcohol intake, are recommended to prevent acute pancreatitis consistent with current guidelines. ${ }^{4}$

The Panel believes there is insufficient evidence to permit definition of targets for triglycerides or HDL-C for these high-risk patients. Instead, the Panel proposes that treatment should be tailored to the individual to achieve desirable levels below (for triglycerides or non-HDL-C) or above (for HDL-C) the recommended cut-offs (Box 6). The Panel acknowledges that other expert bodies recommend apo $B$ as a secondary therapeutic target in hypertriglyceridaemic patients, ${ }^{18.19}$ but considers that the precise clinical yield of this approach has yet to be demonstrated. The Panel also recognizes the limitations of the current evidence base for fibrates, niacin, and omega-3 fatty acids, including the lack of hard outcome data for statin-niacin and statin-omega-3 fatty acid combination therapies. Clearly, there is a need for well-defined trials to evaluate the efficacy and safety of these therapeutic combinations in high-risk patients at LDL-C goal with elevated triglycerides and/ or low HDL-C.

\section{Box 6 Desirable lipid levels in patients at high risk of CVD, according to recent European guidelines ${ }^{4}$}

$$
\begin{array}{ll}
\text { LDL-C } & <2.5 \mathrm{mmol} / \mathrm{L}(100 \mathrm{mg} / \mathrm{dL}) \text { in high risk; } \\
& <2.0 \mathrm{mmol} / \mathrm{L}(80 \mathrm{mg} / \mathrm{dL}) \text { in very high risk } \\
\text { Triglycerides } & <1.7 \mathrm{mmol} / \mathrm{L}(150 \mathrm{mg} / \mathrm{dL}) \\
\text { HDL-C } & >1.0 \mathrm{mmol} / \mathrm{L}(40 \mathrm{mg} / \mathrm{dL}) \text { in men; } \\
& >1.2 \mathrm{mmol} / /(45 \mathrm{mg} / \mathrm{dL}) \text { in women } \\
\text { Non-HDL-C } & <2.5 \mathrm{mmol} / \mathrm{L}(100 \mathrm{mg} / \mathrm{dL})
\end{array}
$$

\section{Conclusions}

The EAS Consensus Panel believes that adoption of these recommendations for clinical management of elevated triglycerides, a marker of TRL and their remnants, and/or low concentrations of HDL-C, supported by appraisal of the current evidence, will facilitate reduction in the substantial CV risk that persists in high-risk patients at LDL-C goal, especially those with cardiometabolic abnormalities (Box 7).

\section{Box 7 Key messages}

- High-risk individuals, especially with cardiometabolic disease, who achieve LDL-C goals remain at high risk of CV events

- Appraisal of the current evidence base implicates elevated triglycerides, a marker of TRL and their remnants, and low levels of HDL-C in this excess CV risk

- In clinical intervention studies using surrogate outcome measures, the addition of niacin to statin reduced atherosclerosis progression in high-risk patients with low LDL-C and elevated triglycerides and/or low HDL-C. Subgroup analyses also showed additional reduction in $\mathrm{CV}$ events with fibrate therapy, either alone or in combination with a statin, in patients with atherogenic dyslipidaemia

- Consistent with European guidelines, ${ }^{4}$ elevated triglycerides $(\geq 1.7 \mathrm{mmol} / \mathrm{L}$ or $150 \mathrm{mg} / \mathrm{dL}$ ) and/or low HDL-C levels $(<1.0 \mathrm{mmol} / \mathrm{L}$ or $40 \mathrm{mg} / \mathrm{dL}$ ) should be triggers for considering further treatment in high-risk individuals

- Lifestyle intervention and addressing compliance and secondary causes of dyslipidaemia constitutes the first step in management

- Adding niacin or a fibrate, or intensifying LDL-C lowering, are suggested options for correction of atherogenic dyslipidaemia

\section{Authors' contribution}

European Atherosclerosis Society Consensus Panel:

Co-chairs: John Chapman and Henry Ginsberg.

The EAS Consensus Panel met four times during the preparation of this manuscript. At the first meeting, members of the Panel critically reviewed the available evidence based on the published literature and at subsequent meetings scrutinized the draft manuscript. All members of the EAS Consensus Panel were involved in the writing of the manuscript and approved the final manuscript before submission.

\section{Supplementary material}

Supplementary material is available at European Heart Journal online.

\section{Acknowledgements}

Jane Stock provided outstanding editorial support to the Consensus Panel.

\section{Funding}

This work including Consensus Panel meetings were supported by unrestricted educational grants to the EAS from Merck, Kowa, Roche, and AstraZeneca. This funding also supported the Open Access publication charges for this article. These companies were not present at the Consensus Panel meetings, had no role in the design or content of the Consensus Statement, and had no right to approve or disapprove of the final document. 
Conflict of interest: several of the Consensus Panel members have received lecture honoraria, consultancy fees, and/or research funding from Abbott (A.L.C., O.S.D., H.G., B.G.N., K.R., Z.R., L.T., G.W.); Astra Zeneca (F.A., J.B., A.L.C., J.C., O.S.D., E.F., H.G., P.T.K., L.M., B.G.N., K.R., Z.R., L.T., G.W.); Bayer (F.A.); Boehringer Ingelheim (F.A., A.L.C., B.G.N., M.R.T., G.W.); Bristol-Myers Squibb (F.A., K.R., L.T.); Daiichi-Sankyo (F.A., K.R., L.T.); Glaxo-Welcome (G.W.); Karo Bio (B.G.N.); Kowa (L.M., M.R.T.); Lilly (F.A., K.R., M.R.T.); Menarini (K.R., L.T.); Merck (F.A., J.B., A.L.C., J.C., O.S.D., E.F., H.G., P.T.K., L.M., K.R., Z.R., L.T., R.T., G.W.); Novartis (L.M., K.R., L.T., M.R.T., L.M., G.W.); Pfizer (F.A., J.B., A.L.C., J.C., O.S.D., H.G., P.T.K., B.G.N., K.R., Z.R., L.T., G.W.), Sanofi-Aventis (A.L.C., J.B., O.S.D., B.G.N., K.R., L.T., M.R.T., G.W.); Takeda (E.F., M.R.T.).

\section{References}

1. European Cardiovascular Disease Statistics. 2008. http://www.heartstats.org/ datapage.asp?id=7683 (2 November 2010).

2. Annual Report of the EHN activities and its members in 2008. http://www. ehnheart.org/publications/annual-reports.html (28 May 2010).

3. Shaw JE, Sicree RA, Zimmet PZ. Global estimates of the prevalence of diabetes for 2010 and 2030. Diabetes Res Clin Pract 2010;87:4-14.

4. Graham I, Atar D, Borch-Johnsen K, Boysen G, Burell G, Cifkova R, Dallongeville J, De Backer G, Ebrahim S, Gjelsvik B, Herrmann-Lingen C, Hoes A, Humphries S, Knapton M, Perk J, Priori SG, Pyorala K, Reiner Z, Ruilope L, Sans-Menendez S, Scholte op Reimer W, Weissberg P, Wood D, Yarnell J, Zamorano JL, Walma E, Fitzgerald T, Cooney MT, Dudina A, European Society of Cardiology (ESC) Committee for Practice Guidelines (CPG). European guidelines on cardiovascular disease prevention in clinical practice: executive summary: Fourth Joint Task Force of the European Society of Cardiology and Other Societies on Cardiovascular Disease Prevention in Clinical Practice (Constituted by representatives of nine societies and by invited experts). Eur Heart J 2007;28:2375-2414.

5. Grundy SM, Cleeman JI, Merz CN, Brewer HB Jr, Clark LT, Hunninghake DB, Pasternak RC, Smith SC Jr, Stone NJ, Coordinating Committee of the National Cholesterol Education Program. Implications of recent clinical trials for the National Cholesterol Education Program Adult Treatment Panel III Guidelines. Arterioscler Thromb Vasc Biol 2004;24:e149-e161.

6. Wiviott SD, Braunwald E, McCabe CH, Montalescot G, Ruzyllo W, Gottlieb S, Neumann FJ, Ardissino D, De Servi S, Murphy SA, Riesmeyer J, Weerakkody G, Gibson CM, Antman EM, TRITON-TIMI 38 Investigators. Prasugrel versus clopidogrel in patients with acute coronary syndromes. N Engl J Med 2007;357: 2001-2015.

7. Wallentin L, Becker RC, Budaj A, Cannon CP, Emanuelsson H, Held C, Horrow J, Husted S, James S, Katus H, Mahaffey KW, Scirica BM, Skene A, Steg PG, Storey RF, Harrington RA, PLATO Investigators, Freij A, Thorsén M. Ticagrelor versus clopidogrel in patients with acute coronary syndromes. $N$ Engl J Med 2009;361:1045-1057.

8. Ray KK, Cannon CP, McCabe CH, Cairns R, Tonkin AM, Sacks FM, Jackson G, Braunwald E, PROVE IT-TIMI 22 Investigators. Early and late benefits of highdose atorvastatin in patients with acute coronary syndromes: results from the PROVE IT-TIMI 22 trial. J Am Coll Cardiol 2005;46:1405-1410.

9. Ahmed S, Cannon CP, Murphy SA, Braunwald E. Acute coronary syndromes and diabetes: is intensive lipid lowering beneficial? Results of the PROVE IT-TIMI 22 trial. Eur Heart J 2006;27:2323-2329.

10. Deedwania P, Barter P, Carmena R, Fruchart JC, Grundy SM, Haffner S, Kastelein JJ, LaRosa JC, Schachner H, Shepherd J, Waters DD, Treating to New Targets Investigators. Reduction of low-density lipoprotein cholesterol in patients with coronary heart disease and metabolic syndrome: analysis of the Treating to New Targets study. Lancet 2006;368:919-928.

11. Miller M, Cannon CP, Murphy SA, Qin J, Ray KK, Braunwald E, PROVE IT-TIMI 22 Investigators. Impact of triglyceride levels beyond low-density lipoprotein cholesterol after acute coronary syndrome in the PROVE IT-TIMI 22 trial. J Am Coll Cardiol 2008;51:724-730.

12. Barter P, Gotto AM, LaRosa JC, Maroni J, Szarek M, Grundy SM, Kastelein JJ, Bittner V, Fruchart JC, Treating to New Targets Investigators. HDL cholesterol, very low levels of LDL cholesterol, and cardiovascular events. N Engl J Med 2007; 357:1301-1310.

13. Olsson AG, Schwartz GG, Szarek M, Sasiela WJ, Ezekowitz MD, Ganz P, Oliver MF, Waters D, Zeiher A. High-density lipoprotein, but not low-density lipoprotein cholesterol levels influence short-term prognosis after acute coronary syndrome: results from the MIRACL trial. Eur Heart J 2005;26:890-896.
14. Wolfram RM, Brewer HB, Xue Z, Satler LF, Pichard AD, Kent KM, Waksman R. Impact of low high-density lipoproteins on in-hospital events and one-year clinical outcomes in patients with non-ST-elevation myocardial infarction acute coronary syndrome treated with drug-eluting stent implantation. Am J Cardiol 2006; 98:711-717.

15. Turner RC, Millns H, Neil HA, Stratton IM, Manley SE, Matthews DR, Holman RR. Risk factors for coronary artery disease in non-insulin dependent diabetes mellitus: United Kingdom Prospective Diabetes Study (UKPDS: 23). BMJ 1998;316:823-828.

16. Rydén L, Standl E, Bartnik M, Van den Berghe G, Betteridge J, de Boer MJ, Cosentino F, Jönsson B, Laakso M, Malmberg K, Priori S, Ostergren J, Tuomilehto J, Thrainsdottir I, Vanhorebeek I, Stramba-Badiale M, Lindgren P, Qiao Q, Priori SG, Blanc J, Budaj A, Camm J, Dean V, Deckers J, Dickstein K, Lekakis J, McGregor K, Metra M, Morais J, Osterspey A, Tamargo J, Zamorano JL, Deckers JW, Bertrand M, Charbonnel B, Erdmann E, Ferrannini E, Flyvbjerg A, Gohlke H, Juanatey JR, Graham I, Monteiro PF, Parhofer K, Pyörälä K, Raz I, Schernthaner G, Volpe M, Wood D, Task Force on Diabetes and Cardiovascular Diseases of the European Society of Cardiology (ESC), European Association for the Study of Diabetes (EASD). Guidelines on diabetes, pre-diabetes, and cardiovascular diseases: executive summary. The Task Force on Diabetes and Cardiovascular Diseases of the European Society of Cardiology (ESC) and of the European Association for the Study of Diabetes (EASD). Eur Heart J 2007;28:88-136.

17. American Diabetes Association. Standards of medical care in diabetes-2008. Diabetes Care 2008;31(Suppl. 1):S12-S54. [Updated 2009: Executive summary: standards of medical care in diabetes-2009. Diabetes Care 2009;32(Suppl. 1): S6-S12.

18. Brunzell JD, Davidson M, Furberg CD, Goldberg RB, Howard BV, Stein JH, Witztum JL, American Diabetes Association, American College of Cardiology Foundation. Lipoprotein management in patients with cardiometabolic risk. Consensus statement from the American Diabetes Association and the American College of Cardiology Foundation. Diabetes Care 2008;31:811-821.

19. Genest J, McPherson R, Frohlich J, Anderson T, Campbell N, Carpentier A, Couture P, Dufour R, Fodor G, Francis GA, Grover S, Gupta M, Hegele RA, Lau DC, Leiter L, Lewis GF, Lonn E, Mancini GB, Ng D, Pearson G], Sniderman A, Stone JA, Ur E. 2009 Canadian Cardiovascular Society/Canadian guidelines for the diagnosis and treatment of dyslipidemia and prevention of cardiovascular disease in the adult-2009 recommendations. Can J Cardiol 2009;25: 567-579.

20. Ginsberg HN. New perspectives on atherogenesis. Role of abnormal triglyceride-rich lipoprotein metabolism. Circulation 2002;106:2137-2142.

21. Twickler TB, Dallinga-Thie GM, Cohn JS, Chapman MJ. Elevated remnant-like particle cholesterol concentration: a characteristic feature of the atherogenic lipoprotein phenotype. Circulation 2004;109:1918-1925.

22. Vergeer M, Holleboom AG, Kastelein JJ, Kuivenhoven JA. The HDL hypothesis: does high-density lipoprotein protect from atherosclerosis? J Lipid Res 2010;51: 2058-2073.

23. Rye KA, Bursill CA, Lambert G, Tabet F, Barter PJ. The metabolism and antiatherogenic properties of HDL. J Lipid Res 2009;50(suppl):S195-S200.

24. Havel RJ. Triglyceride-rich lipoproteins and plasma lipid transport. Arterioscler Thromb Vasc Biol 2010;30:9-19.

25. Lassel TS, Guerin M, Auboiron S, Guy-Grand B, Chapman MJ. Evidence for a cholesteryl ester donor activity of LDL particles during alimentary lipemia in normolipidemic subjects. Atherosclerosis 1999;147:41-48.

26. Chan DC, Watts GF. Dyslipidaemia in the metabolic syndrome and type 2 diabetes: pathogenesis, priorities, pharmacotherapies. Expert Opin Pharmacother 2011;12:13-30.

27. Fisher EA. GPIHBP1: lipoprotein lipase's ticket to ride. Cell Metab 2010;12:1-2.

28. Kontush A, Chapman MJ. Functionally defective high-density lipoprotein: a new therapeutic target at the crossroads of dyslipidaemia, inflammation, and atherosclerosis. Pharmacol Rev 2006;58:342-374.

29. Horowitz BS, Goldberg IJ, Merab J, Vanni T, Ramakrishnan R, Ginsberg HN. Increased plasma and renal clearance of an exchangeable pool of apolipoprotein A-I in subjects with low levels of high density lipoprotein cholesterol. J Clin Invest 1993;91:1743-1776.

30. Brunzell JD. Clinical practice. Hypertriglyceridemia. N Engl J Med 2007;357: 1009-1017.

31. Brouwers MC, de Graaf J, van Greevenbroek MM, Schaper N, Stehouwer CD, Stalenhoef AF. Novel drugs in familial combined hyperlipidemia: lessons from type 2 diabetes mellitus. Curr Opin Lipidol 2010;21:530-538.

32. Goldstein JL, Schrott HG, Hazzard WR, Bierman EL, Motulsky AG. Hyperlipidemia in coronary heart disease. II. Genetic analysis of lipid levels in 176 families and delineation of a new inherited disorder, combined hyperlipidemia. J Clin Invest 1973;52:1544-1568. 
33. Wijsman EM, Rothstein JH, Igo RP Jr, Brunzell JD, Motulsky AG, Jarvik GP. Linkage and association analyses identify a candidate region for apoB level on chromosome 4q32.3 in FCHL families. Hum Genet 2010;127:705-719.

34. Williams KJ, Tabas I. The response-to-retention hypothesis of early atherogenesis. Arterioscler Thromb Vasc Biol 1995;15:551-561.

35. European Atherosclerosis Society Consensus Panel. Lipoprotein(a) as a cardiovascular risk factor: current status. Eur Heart J 2010;31:2844-2853.

36. Smith EB, Slater RS. The microdissection of large atherosclerotic plaques to give morphologically and topographically defined fractions for analysis. 1 . The lipids in the isolated fractions. Atherosclerosis 1972;15:37-56.

37. Rohrer L, Ohnsorg PM, Lehner M, Landolt F, Rinninger F, von Eckardstein A. High-density lipoprotein transport through aortic endothelial cells involves scavenger receptor $\mathrm{Bl}$ and ATP-binding cassette transporter G1. Circ Res 2009;104: $1142-1150$.

38. Nordestgaard BG, Stender S, Kjeldsen K. Reduced atherogenesis in cholesterol-fed diabetic rabbits. giant lipoproteins do not enter the arterial wall. Arteriosclerosis 1988;8:421-428.

39. Rapp $J$, Lespine A, Hamilton RL, Colyvas $N$, Chaumeton $A H$, Tweedie-Hardman J, Kotite L, Kunitake ST, Havel RJ, Kane JP. Triglyceride-rich lipoproteins isolated by selected-affinity anti-apolipoprotein B immunosorption from human atherosclerotic plaque. Arterioscler Thromb Vasc Biol 1994;14: 1767-1774.

40. Daugherty A, Lange LG, Sobel BE, Schonfeld G. Aortic accumulation and plasma clearance of $\beta$-VLDL and HDL: effects of diet-induced hypercholesterolemia in rabbits. J Lipid Res 1985;26:955-963.

41. Proctor SD, Mamo JCL. Retention of fluorescent-labelled chylomicron remnants within the intima of the arterial wall—evidence that plaque cholesterol may be derived from post-prandial lipoproteins. Eur J Clin Invest 1998;28:497-504.

42. Goldstein JL, Ho YK, Brown MS, Innerarity TL, Mahley RW. Cholesteryl ester accumulation in macrophages resulting from receptor-mediated uptake and degradation of hypercholesterolemic canine beta-very low density lipoproteins. J Biol Chem 1980;255:1839-1848.

43. Pitas RE, Innerarity TL, Mahley RW. Foam cells in explants of atherosclerotic rabbit aortas have receptors for beta-very low density lipoproteins and modified low density lipoproteins. Arteriosclerosis 1983;3:2-12.

44. Alaupovic P, Mack WJ, Knight-Gibson C, Hodis HN. The role of triglyceride-rich lipoprotein families in the progression of atherosclerotic lesions as determined by sequential coronary angiography from a controlled clinical trial. Arterioscler Thromb Vasc Biol 1997;17:715-722.

45. Grønholdt ML, Nordestgaard BG, Nielsen TG, Sillesen H. Echolucent carotid artery plaques are associated with elevated levels of fasting and postprandial triglyceride-rich lipoproteins. Stroke 1996;27:2166-2172.

46. Zheng $X Y$, Liu L. Remnant-like lipoprotein particles impair endothelial function: direct and indirect effects on nitric oxide synthase. J Lipid Res 2007;48: 1673-1680.

47. Giannattasio C, Zoppo A, Gentile G, Failla M, Capra A, Maggi FM, Catapano A, Mancia G. Acute effect of high-fat meal on endothelial function in moderately dyslipidemic subjects. Arterioscler Thromb Vasc Biol 2005;25:406-410.

48. Zilversmit DB. Atherogenesis: a postprandial phenomenon. Circulation 1979;60: $473-485$.

49. Alipour A, van Oostrom AJ, Izraeljan A, Verseyden C, Collins JM, Frayn KN, Plokker TW, Elte JW, Castro Cabezas M. Leukocyte activation by triglyceride-rich lipoproteins. Arterioscler Thromb Vasc Biol 2008;28:792-797.

50. Ting HJ, Stice JP, Schaff UY, Hui DY, Rutledge JC, Knowlton AA, Passerini AG, Simon SI. Triglyceride-rich lipoproteins prime aortic endothelium for an enhanced inflammatory response to tumor necrosis factor-alpha. Circ Res 2007; 100:381-390.

51. Wang L, Gill R, Pedersen TL, Higgins LJ, Newman JW, Rutledge JC. Triglyceride-rich lipoprotein lipolysis releases neutral and oxidized FFAs that induce endothelial cell inflammation. J Lipid Res 2009;50:204-213.

52. Davies MJ. Stability and instability: two faces of coronary atherosclerosis. The Paul Dudley White Lecture 1995. Circulation 1996;94:2013-2020.

53. Falk E, Shah PK, Fuster V. Coronary plaque disruption. Circulation 1995;92: 657-671.

54. Sambola A, Osende J, Hathcock J, Degen M, Nemerson Y, Fuster V, Crandall J, Badimon JJ. Role of risk factors in the modulation of tissue factor activity and blood thrombogenicity. Circulation 2003;107:973-977.

55. Moyer MP, Tracy RP, Tracy PB, van't Veer C, Sparks CE, Mann KG. Plasma lipoproteins support prothrombinase and other procoagulant enzymatic complexes. Arterioscler Thromb Vasc Biol 1998;18:458-465.

56. Kohler HP, Grant PJ. Plasminogen-activator inhibitor type 1 and coronary artery disease. N Engl J Med 2000;342:1792-1801.

57. Grant PJ. Diabetes mellitus as a prothrombotic condition. J Intern Med 2007;262: $157-172$.
58. Rütti S, Ehses JA, Sibler RA, Prazak R, Rohrer L, Georgopoulos S, Meier DT, Niclauss N, Berney T, Donath MY, von Eckardstein A. Low- and high-density lipoproteins modulate function, apoptosis, and proliferation of primary human and murine pancreatic beta-cells. Endocrinology 2009;150:4521-4530.

59. Fryirs MA, Barter PJ, Appavoo M, Tuch BE, Tabet F, Heather AK, Rye KA. Effects of high-density lipoproteins on pancreatic beta-cell insulin secretion. Arterioscler Thromb Vasc Biol 2010;30:1642-1648.

60. Getz GS, Reardon CA. High-density lipoprotein function in regulating insulin secretion: possible relevance to metabolic syndrome. Arterioscler Thromb Vasc Biol 2010;30:1497-1499.

61. Mineo C, Deguchi H, Griffin JH, Shaul PA. Endothelial and antithrombotic actions of HDL. Circ Res 2006;98:1352-1364.

62. Tso C, Martinic G, Fan WH, Rogers C, Rye KA, Barter PJ. High-density lipoproteins enhance progenitor-mediated endothelium repair in mice. Arterioscler Thrombosis Vasc Biol 2006;26:1144-1149.

63. Murphy AJ, Woollard KJ, Hoang A, Mukhamedova N, Stirzaker RA, McCormick SP, Remaley AT, Sviridov D, Chin-Dusting J. High-density lipoprotein reduces the human monocyte inflammatory response. Arterioscler Thromb Vasc Biol 2008;28:2071-2077.

64. Wilhelm AJ, Zabalawi M, Grayson JM, Weant AE, Major AS, Owen J, Bharadwaj M, Walzem R, Chan L, Oka K, Thomas MJ, Sorci-Thomas MG. Apolipoprotein A-I and its role in lymphocyte cholesterol homeostasis and autoimmunity. Arterioscler Thromb Vasc Biol 2009;29:843-849.

65. Rosenson RS, Brewer HB Jr, Chapman MJ, Fazio S, Hussain MM, Kontush A Krauss RM, Otvos JD, Remaley AT, Schaefer EJ. HDL measures, particle heterogeneity, proposed nomenclature, and relation to atherosclerotic cardiovascular events. Clin Chem 2011;57:392-410.

66. Epand RM, Stafford A, Leon B, Lock PE, Tytler EM, Segrest JP, Anantharamaiah GM. HDL and apolipoprotein A-I protect erythrocytes against the generation of procoagulant activity. Arterioscler Thromb 1994;14: $1775-1783$.

67. Griffin JH, Kojima K, Banka CL, Curtiss LK, Fernández JA. High-density lipoprotein enhancement of anticoagulant activities of plasma protein $\mathrm{S}$ and activated protein C. J Clin Invest 1999;103:219-227.

68. Nofer JR, Walter M, Kehrel B, Wierwille S, Tepel M, Seedorf U, Assmann G. HDL3-mediated inhibition of thrombin-induced platelet aggregation and fibrinogen binding occurs via decreased production of phosphoinositide-derived second messengers 1,2-diacylglycerol and inositol 1,4,5-tris-phosphate. Arterioscler Thromb Vasc Biol 1998;18:861-869.

69. Patel S, Drew BG, Nakhla S, Duffy SJ, Murphy AJ, Barter PJ, Rye KA Chin-Dusting J, Hoang A, Sviridov D, Celermajer DS, Kingwell BA. Reconstituted high-density lipoprotein increases plasma high-density lipoprotein antiinflammatory properties and cholesterol efflux capacity in patients with type 2 diabetes. J Am Coll Cardiol 2009;53:962-971.

70. Calkin AC, Drew BG, Ono A, Duffy SJ, Gordon MV, Schoenwaelder SM, Sviridov D, Cooper ME, Kingwell BA, Jackson SP. Reconstituted high-density lipoprotein attenuates platelet function in individuals with type 2 diabetes mellitus by promoting cholesterol efflux. Circulation 2009;120:2095-2104.

71. Khera AV, Cuchel M, de la Llera-Moya M, Rodrigues A, Burke MF, Jafri $K$ French BC, Phillips JA, Mucksavage ML, Wilensky RL, Mohler ER, Rothblat GH, Rader DJ. Cholesterol efflux capacity, high-density lipoprotein function, and atherosclerosis. N Engl J Med 2011;364:127-135.

72. Rubin EM, Krauss RM, Spangler EA, Verstuyft JG, Clift SM. Inhibition of early atherogenesis in transgenic mice by human apolipoprotein Al. Nature 1991; 353:265-267.

73. Badimon JJ, Badimon L, Fuster V. Regression of atherosclerotic lesions by high density lipoprotein plasma fraction in the cholesterol-fed rabbit. J Clin Invest 1990;85:1234-1241.

74. Chiesa G, Monteggia E, Marchesi M, Lorenzon P, Laucello M, Lorusso V, Di Mario C, Karvouni E, Newton RS, Bisgaier CL, Franceschini G, Sirtori CR. Recombinant apolipoprotein A-I(Milano) infusion into rabbit carotid artery rapidly removes lipid from fatty streaks. Circ Res 2002;90:974-980.

75. Spieker LE, Sudano I, Hürlimann D, Lerch PG, Lang MG, Binggeli C, Corti R, Ruschitzka F, Lüscher TF, Noll G. High-density lipoprotein restores endothelial function in hypercholesterolemic men. Circulation 2002;105:1399-1402.

76. Nissen SE, Tsunoda T, Tuzcu EM, Schoenhagen P, Cooper CJ, Yasin M, Eaton GM, Lauer MA, Sheldon WS, Grines CL, Halpern S, Crowe T, Blankenship JC, Kerensky R. Effect of recombinant ApoA-I Milano on coronary atherosclerosis in patients with acute coronary syndromes: a randomized controlled trial. JAMA 2003;290:2292-2300.

77. Tardif JC, Gregoire J, L'Allier PL, Ibrahim R, Lesperance J, Heinonen TM, Kouz S Berry C, Basser R, Lavoie MA, Guertin MC, Rodes-Cabau J. Effects of reconstituted high-density lipoprotein infusions on coronary atherosclerosis: a randomized controlled trial. JAMA 2007;297:1675-1682. 
78. Shaw JA, Bobik A, Murphy A, Kanellakis P, Blombery P, Mukhamedova N, Woollard K, Lyon S, Sviridov D, Dart AM. Infusion of reconstituted high-density lipoprotein leads to acute changes in human atherosclerotic plaque. Circ Res 2008;103:1084-1091

79. Nicholls SJ, Tuzcu EM, Sipahi I, Grasso AW, Schoenhagen P, Hu T, Wolski K, Crowe T, Desai MY, Hazen SL, Kapadia SR, Nissen SE. Statins, high-density lipoprotein cholesterol, and regression of coronary atherosclerosis. JAMA 2007;297: 499-508.

80. Taskinen MR. Type 2 diabetes as a lipid disorder. Curr Mol Med 2005;5:297-308.

81. Hodoğlugil U, Williamson DW, Mahley RW. Polymorphisms in the hepatic lipase gene affect plasma HDL-cholesterol levels in a Turkish population. J Lipid Res 2010;51:422-430.

82. Mahley RW, Palaogiu KE, Atak Z, Dawaon-Pepin J, Langlois A-M, Cheung V, Onat H, Fulks P, Mahley LL, Vakar F, Ozbayrakq S, Giikdemir O, Winkler W. Turkish Heart Study: lipids, lipoproteins, and apolipoproteins. J Lipid Res 1995; 36:839-859.

83. Sanisoglu SY, Oktenli C, Hasimi A, Yokusoglu M, Ugurlu M. Prevalence of metabolic syndrome-related disorders in a large adult population in Turkey. BMC Public Health 2006;6:92. doi:10.1186/1471-2458-6-92.

84. Eriksson M, Zethelius B, Eeg-Olofsson K, Nilsson PM, Gudbjörnsdottir S, Cederholm J, Eliasson B. Blood lipids in 75048 type 2 diabetic patients: a population-based survey from the Swedish National diabetes register. Eur J Cardiovasc Prev Rehab 2011;18:97-105.

85. Kotseva K, Wood D, De Backer G, De Bacquer D, Pyörälä K, Keil U, EUROASPIRE Study Group. EUROASPIRE III: a survey on the lifestyle, risk factors and use of cardioprotective drug therapies in coronary patients from 22 European countries. Eur J Cardiovasc Prev Rehabil 2009;16:121-137.

86. Assmann G, Cullen P, Schulte H. Non-LDL-related dyslipidemia and coronary risk: a case-control study. Diab Vasc Dis Res 2010;7:204-212.

87. Austin MA. Plasma triglyceride and coronary heart disease. Arterioscler Thromb 1991;11:2-14.

88. Hokanson JE, Austin MA. Plasma triglyceride level is a risk factor for cardiovascular disease independent of high-density lipoprotein cholesterol level: a meta-analysis of population-based prospective studies. J Cardiovasc Risk 1996;3: 213-219.

89. Nordestgaard BG, Benn M, Schnohr P, Tybjærg-Hansen A. Nonfasting triglycerides and risk of myocardial infarction, ischemic heart disease, and death in men and women. JAMA 2007;298:299-308.

90. Freiberg JJ, Tybjærg-Hansen A, Jensen JS, Nordestgaard BG. Nonfasting triglycerides and risk of ischemic stroke in the general population. JAMA 2008;300: 2142-2152.

91. Gordon DJ, Probstfield JL, Garrison RJ, Neaton JD, Castelli WP, Knoke JD, Jacobs DR Jr, Bangdiwala S, Tyroler HA. High-density lipoprotein cholesterol and cardiovascular disease. Four prospective American studies. Circulation 1989;79:8-15.

92. Jacobs DR Jr, Mebane IL, Bangdiwala SI, Criqui MH, Tyroler HA. High density lipoprotein cholesterol as a predictor of cardiovascular disease mortality in men and women: the follow-up study of the Lipid Research Clinics Prevalence Study. Am J Epidemiol 1990;131:32-47.

93. The Emerging Risk Factors Collaboration. Major lipids, apolipoproteins, and risk of vascular disease. JAMA 2009;302:1993-2000.

94. Mahley RW, Rall SC Jr. Type III hyperlipoproteinemia (dysbetalipoproteinemia): the role of apolipoprotein $E$ in normal and abnormal lipoprotein metabolism. In: Scriver C, Beaudet A, Sly W, Valle D (eds), The Metabolic and Molecular Bases of Inherited Disease. 8th ed. New York: McGraw-Hill Inc; 2001, p2705-2960.

95. Benlian P, De Gennes JL, Foubert L, Zhang H, Gagné SE, Hayden M. Premature atherosclerosis in patients with familial chylomicronemia caused by mutations in the lipoprotein lipase gene. N Engl J Med 1996;335:848-854 [Erratum in: N Engl J Med 1997;336:451].

96. Weinstein MM, Yin L, Tu Y, Wang X, Wu X, Castellani LW, Walzem RL, Lusis AJ, Fong LG, Beigneux AP, Young SG. Chylomicronemia elicits atherosclerosis in mice-brief report. Arterioscler Thromb Vasc Biol 2010;30:20-23.

97. Nordestgaard BG, Zilversmit DB. Large lipoproteins are excluded from the arterial wall in diabetic cholesterol-fed rabbits. J Lipid Res 1988;29:1491-1500.

98. Amarenco P, Goldstein LB, Messig M, O'Neill BJ, Callahan A 3rd, Sillesen H, Hennerici MG, Zivin JA, Welch KM, SPARCL Investigators. Relative and cumulative effects of lipid and blood pressure control in the Stroke Prevention by Aggressive Reduction in Cholesterol Levels trial. Stroke 2009;40:2486-2492.

99. Baigent C, Keech A, Kearney PM, Blackwell L, Buck G, Pollicino C, Kirby A, Sourjina T, Peto R, Collins R, Simes R, Cholesterol Treatment Trialists' (CTT) Collaborators. Efficacy and safety of cholesterol-lowering treatment: prospective meta-analysis of data from 90056 participants in 14 randomised trials of statins. Lancet 2005;366:1267-1278.
100. Cholesterol Treatment Trialists' Ctt Collaboration. Efficacy and safety of more intensive lowering of LDL cholesterol: a meta-analysis of data from 170000 participants in 26 randomised trials. Lancet 2010;376:1670-1681.

101. Briel M, Ferreira-Gonzalez I, You J], Karanicolas PJ, Akl EA, Wu P, Blechacz B, Bassler D, Wei X, Sharman A, Whitt I, Alves da Silva S, Khalid Z, Nordmann AJ, Zhou Q, Walter SD, Vale N, Bhatnagar N, O'Regan C, Mills EJ, Bucher HC, Montori VM, Guyatt GH. Association between change in high density lipoprotein cholesterol and cardiovascular disease morbidity and mortality: systematic review and meta-regression analysis. BMJ 2009;338:b92.

102. Ridker PM, Genest J, Boekholdt SM, Libby P, Gotto AM, Nordestgaard BG, Mora S, MacFadyen JG, Glynn RJ, Kastelein JJP, for the JUPITER Trial Study Group. HDL cholesterol and residual risk of first cardiovascular events after treatment with potent statin therapy: an analysis from the JUPITER trial. Lancet 2010;376:333-339.

103. Pedersen TR, Olsson AG, Faergeman O, Kjekshus J, Wedel H, Berg K, Wilhelmsen L, Haghfelt T, Thorgeirsson G, Pyörälä K, Miettinen T, Christophersen B, Tobert JA, Musliner TA, Cook TJ. Lipoprotein changes and reduction in the incidence of major coronary heart disease events in the Scandinavian Simvastatin Survival Study (4S). Circulation 1998;97:1453-1460.

104. Faergeman O, Holme I, Fayyad R, Bhatia S, Grundy SM, Kastelein JJ, LaRosa JC, Larsen ML, Lindahl C, Olsson AG, Tikkanen MJ, Waters DD, Pedersen TR, Steering Committees of IDEAL and TNT Trials. Plasma triglycerides and cardiovascular events in the Treating to New Targets and Incremental Decrease in End-Points through Aggressive Lipid Lowering trials of statins in patients with coronary artery disease. Am J Cardiol 2009;104:459-463.

105. Kastelein J], van der Steeg WA, Holme I, Gaffney M, Cater NB, Barter P, Deedwania P, Olsson AG, Boekholdt SM, Demicco DA, Szarek M, LaRosa JC, Pedersen TR, Grundy SM, TNT Study Group, IDEAL Study Group. Lipids, apolipoproteins, and their ratios in relation to cardiovascular events with statin treatment. Circulation 2008;117:3002-3009.

106. Scott R, O'Brien R, Fulcher G, Pardy C, D'Emden M, Tse D, Taskinen MR, Ehnholm C, Keech A, Fenofibrate Intervention and Event Lowering in Diabetes (FIELD) Study Investigators. Effects of fenofibrate treatment on cardiovascular disease risk in 9,795 individuals with type 2 diabetes and various components of the metabolic syndrome: the Fenofibrate Intervention and Event Lowering in Diabetes (FIELD) study. Diabetes Care 2009;32:493-498.

107. ACCORD Study Group, Ginsberg HN, Elam MB, Lovato LC, Crouse JR 3rd, Leiter LA, Linz P, Friedewald WT, Buse JB, Gerstein HC, Probstfield J, Grimm RH, Ismail-Beigi F, Bigger JT, Goff DC Jr, Cushman WC, Simons-Morton DG, Byington RP. Effects of combination lipid therapy in type 2 diabetes mellitus. N Eng J Med 2010;362:1563-1574.

108. Taskinen MR, Barter PJ, Ehnholm C, Sullivan DR, Mann K, Simes J, Best JD, Hamwood S, Keech AC, on behalf of the FIELD Study Investigators. Ability of traditional lipid ratios and apolipoprotein ratios to predict cardiovascular risk in people with type 2 diabetes. Diabetologia 2010;53:1846-1855.

109. Hegele RA. Plasma lipoproteins: genetic influences and clinical implications. Nat Rev Genet 2009;10:109-121.

110. Wittrup HH, Tybjærg-Hansen A, Nordestgaard BG. Lipoprotein lipase mutations, plasma lipids and lipoproteins, and risk of ischemic heart disease: a meta-analysis. Circulation 1999;99:2901-2907.

111. Hokanson JE. Lipoprotein lipase gene variants and risk of coronary disease: a quantitative analysis of population-based studies. Int J Clin Lab Res 1997;27: 24-34.

112. Johansen CT, Wang J, Lanktree MB, Cao H, Mclntyre AD, Ban MR, Martins RA, Kennedy BA, Hassell RG, Visser ME, Schwartz SM, Voight BF, Elosua R, Salomaa V, O'Donnell C], Dallinga-Thie GM, Anand SS, Yusuf S, Huff MW, Kathiresan S, Hegele RA. Excess of rare variants in genes identified by genomewide association study of hypertriglyceridemia. Nat Genet 2010;42:684-687.

113. Hu Y, Liu W, Huang R, Zhang X. A systematic review and metaanalysis of the relationship between lipoprotein lipase Asn291Ser variant and diseases. J Lipid Res 2006;47:1908-1914.

114. Thompson A, Di Angelantonio E, Sarwar N, Erqou S, Saleheen D, Dullaart RPF, Keavney B, Ye Z, Danesh J. Association of cholesteryl ester transfer protein genotypes with CETP mass and activity, lipid levels, and coronary risk. JAMA 2008; 299:2777-2788.

115. Teslovich TM, Musunuru K, Smith AV, Edmondson AC, Stylianou IM, Koseki M, Pirruccello JP, Ripatti S, Chasman DI, Willer CJ, Johansen CT, Fouchier SW, Isaacs A, Peloso GM, Barbalic M, Ricketts SL, Bis JC, Aulchenko YS, Thorleifsson G, Feitosa MF, Chambers J, Orho-Melander M, Melander O, Johnson T, Li X, Guo X, Li M, Shin Cho Y, Jin Go M, Jin Kim Y, Lee JY, Park T, Kim K, Sim X, Twee-Hee Ong R, Croteau-Chonka DC, Lange LA, Smith JD, Song K, Hua Zhao J, Yuan X, Luan J, Lamina C, Ziegler A, Zhang W, Zee RY, Wright AF, Witteman JC, Wilson JF, Willemsen G, Wichmann HE, Whitfield JB, Waterworth DM, Wareham NJ, Waeber G, Vollenweider P, Voight BF, Vitart V, Uitterlinden AG, Uda M, Tuomilehto J, 
Thompson JR, Tanaka T, Surakka I, Stringham HM, Spector TD, Soranzo N, Smit JH, Sinisalo J, Silander K, Sijbrands EJ, Scuteri A, Scott J, Schlessinger D, Sanna S, Salomaa V, Saharinen J, Sabatti C, Ruokonen A, Rudan I, Rose LM, Roberts R, Rieder M, Psaty BM, Pramstaller PP, Pichler I, Perola M, Penninx BW, Pedersen NL, Pattaro C, Parker AN, Pare G, Oostra BA, O'Donnell C], Nieminen MS, Nickerson DA, Montgomery GW, Meitinger T, McPherson R, McCarthy MI, McArdle W, Masson D, Martin NG, Marroni F, Mangino M, Magnusson PK, Lucas G, Luben R, Loos RJ, Lokki ML, Lettre G, Langenberg C, Launer LJ, Lakatta EG, Laaksonen R, Kyvik KO, Kronenberg F, König IR, Khaw KT, Kaprio J, Kaplan LM, Johansson A, Jarvelin MR, Cecile JW, Janssens A, Ingelsson E, Igl W, Kees Hovingh G, Hottenga JJ, Hofman A, Hicks AA, Hengstenberg C, Heid IM, Hayward C, Havulinna AS, Hastie ND, Harris TB, Haritunians T, Hall AS, Gyllensten U, Guiducci C, Groop LC, Gonzalez E, Gieger C, Freimer NB, Ferrucci L, Erdmann J, Elliott P, Ejebe KG, Döring A, Dominiczak AF, Demissie S, Deloukas P, de Geus EJ, de Faire U, Crawford G, Collins FS, Chen YD, Caulfield MJ, Campbell H, Burtt NP, Bonnycastle LL, Boomsma DI, Boekholdt SM, Bergman RN, Barroso I, Bandinelli S, Ballantyne CM, Assimes TL, Quertermous T, Altshuler D, Seielstad M, Wong TY, Tai ES, Feranil AB, Kuzawa CW, Adair LS, Taylor HA Jr, Borecki IB, Gabriel SB, Wilson JG, Holm H, Thorsteinsdottir U, Gudnason V, Krauss RM, Mohlke KL, Ordovas JM, Munroe PB, Kooner JS, Tall AR, Hegele RA, Kastelein JJ, Schadt EE, Rotter Jl, Boerwinkle E, Strachan DP, Mooser V, Stefansson K, Reilly MP, Samani NJ, Schunkert H, Cupples LA, Sandhu MS, Ridker PM, Rader DJ, van Duijn CM, Peltonen L, Abecasis GR, Boehnke M, Kathiresan S. Biological, clinical and population relevance of 95 loci for blood lipids. Nature 2010;466:707-713.

116. Triglyceride Coronary Disease Genetics Consortium and Emerging Risk Factors Collaboration, Sarwar N, Sandhu MS, Ricketts SL, Butterworth AS, Di Angelantonio E, Boekholdt SM, Ouwehand W, Watkins H, Samani NJ, Saleheen D, Lawlor D, Reilly MP, Hingorani AD, Talmud PJ, Danesh J. Triglyceride-mediated pathways and coronary disease: collaborative analysis of 101 studies. Lancet 2010;375:1634-1639.

117. Andersen RV, Wittrup HH, Tybjærg-Hansen A, Steffensen R, Schnohr P, Nordestgaard BG. Hepatic lipase mutations, elevated high-density lipoprotein cholesterol, and increased risk of ischemic heart disease. J Am Coll Cardiol 2003;41:1972-1982.

118. van Acker BA, Botsma GJ, Zwinderman AH, Kuivenhoven JA, Dallinga-Thie GM, Sijbrands EJ, Boer JM, Seidell JC, Jukema JW, Kastelein JJ, Jansen H, Verhoeven AJ, REGRESS Study Group. High HDL cholesterol does not protect against coronary artery disease when associated with combined cholesteryl ester transfer protein and hepatic lipase gene variants. Atherosclerosis 2008;200:161-167.

119. Johannsen $T H$, Kamstrup $P$, Andersen RV, Jensen GB, Sillesen $H$, Tybjærg-Hansen A, Nordestgaard BG. Hepatic lipase, genetically elevated highdensity lipoprotein, and risk of ischemic cardiovascular disease. J Clin Endocrinol Metab 2009;94:1264-1273.

120. Frikke-Schmidt R, Nordestgaard BG, Stene MCA, Sethi AA, Remaley AT, Schnohr P, Grande P, Tybjærg-Hansen A. Association of loss-of-function mutations in the ABCA1 gene with high-density lipoprotein cholesterol levels and risk of ischemic heart disease. JAMA 2008:299:2524-2532.

121. Kathiresan $S$, Melander $O$, Guiducci $C$, Surti A, Burtt NP, Rieder MJ, Cooper GM, Roos C, Voight BF, Havulinna AS, Wahlstrand B, Hedner T, Corella D, Tai ES, Ordovas JM, Berglund G, Vartiainen E, Jousilahti P, Hedblad B, Taskinen MR, Newton-Cheh C, Salomaa V, Peltonen L, Groop L, Altshuler DM, Orho-Melander M. Six new loci associated with blood lowdensity lipoprotein cholesterol, high-density lipoprotein cholesterol or triglycerides in humans. Nat Genet 2008;40:189-197.

122. Willer CJ, Sanna S, Jackson AU, Scuteri A, Bonnycastle LL, Clarke R, Heath SC, Timpson NJ, Najjar SS, Stringham HM, Strait J, Duren WL, Maschio A, Busonero F, Mulas A, Albai G, Swift AJ, Morken MA, Narisu N, Bennett D, Parish S, Shen H, Galan P, Meneton P, Hercberg S, Zelenika D, Chen WM, Li Y, Scott LJ, Scheet PA, Sundvall J, Watanabe RM, Nagaraja R, Ebrahim S, Lawlor DA, Ben-Shlomo Y, Davey-Smith G, Shuldiner AR, Collins R, Bergman RN, Uda M, Tuomilehto J, Cao A, Collins FS, Lakatta E, Lathrop GM, Boehnke M, Schlessinger D, Mohlke KL, Abecasis GR. Newly identified loci that influence lipid concentrations and risk of coronary disease. Nat Genet 2008;40:161-169.

123. Maeda K, Noguchi Y, Fukui T. The effects of cessation from cigarette smoking on the lipid and lipoprotein profiles: a meta-analysis. Prev Med 2003;37:283-290.

124. Dattilo AM, Kris-Etherton PM. Effects of weight reduction on blood lipids and lipoproteins: a meta-analysis. Am J Clin Nutr 1992;56:320-328.

125. Kodama S, Tanaka S, Saito K, Shu M, Sone Y, Onitake F, Suzuki E, Shimano H, Yamamoto S, Kondo K, Ohashi Y, Yamada N, Sone H. Effect of aerobic exercise training on serum levels of high-density lipoprotein cholesterol: a meta-analysis. Arch Intern Med 2007;167:999-1008.
126. Tambalis K, Panagiotakos DB, Kavouras SA, Sidossis LS. Responses of blood lipids to aerobic, resistance, and combined aerobic with resistance exercise training: a systematic review of current evidence. Angiology 2009;60:614-632.

127. Roberts CK, Ng C, Hama S, Eliseo AJ, Barnard RJ. Effect of a short-term diet and exercise intervention on inflammatory/anti-inflammatory properties of $\mathrm{HDL}$ in overweight/obese men with cardiovascular risk factors. J Appl Physiol 2006; 101:1727-1732.

128. Magkos F. Basal very low-density lipoprotein metabolism in response to exercise: mechanisms of hypotriacylglycerolemia. Prog Lipid Res 2009;48:171-190.

129. Magkos F, Tsekouras YE, Prentzas KI, Basioukas KN, Matsama SG, Yanni AE, Kavouras SA, Sidossis LS. Acute exercise-induced changes in basal VLDL-triglyceride kinetics leading to hypotriglyceridemia manifest more readily after resistance than endurance exercise. J Appl Physiol 2008;105: $1228-1236$.

130. Wang Y, Simar D, Fiatarone Singh MA. Adaptations to exercise training within skeletal muscle in adults with type 2 diabetes or impaired glucose tolerance: a systematic review. Diabetes Metab Res Rev 2009;25:13-40.

131. Kelley GA, Kelley KS. Impact of progressive resistance training on lipids and lipoproteins in adults: a meta-analysis of randomized controlled trials. Prev Med 2009;48:9-19.

132. Gaziano JM, Buring JE, Breslow JL, Goldhaber SZ, Rosner B, Van Denburgh M, Willett W, Hennekens $\mathrm{CH}$. Moderate alcohol intake, increased levels of highdensity lipoprotein and its subfractions, and decreased risk of myocardial infarction. N Engl J Med 1993;329:1829-1834.

133. Crouse JR, Grundy SM. Effects of alcohol on plasma lipoproteins and cholesterol and triglyceride metabolism in man. J Lipid Res 1984;25:486-496.

134. Ginsberg H, Olefsky J, Farquhar JW, Reaven GM. Moderate ethanol ingestion and plasma triglyceride levels. A study in normal and hypertriglyceridemic persons. Ann Intern Med 1974;80:143-149.

135. Mensink RP, Zock PL, Kester AD, Katan MB. Effects of dietary fatty acids and carbohydrates on the ratio of serum total to $\mathrm{HDL}$ cholesterol and on serum lipids and apolipoproteins: a meta-analysis of 60 controlled trials. Am J Clin Nutr 2003;77:1146-1155.

136. Appel LJ, Sacks FM, Carey VJ, Obarzanek E, Swain JF, Miller ER 3rd, Conlin PR, Erlinger TP, Rosner BA, Laranjo NM, Charleston J, McCarron P, Bishop LM, OmniHeart Collaborative Research Group. Effects of protein, monosaturated fat, and carbohydrate intake on blood pressure and serum lipids: results of the OmniHeart randomized trial. JAMA 2005;294:2455-2464.

137. Nicholls SJ, Lundman P, Harmer JA, Cutri B, Griffiths KA, Rye KA, Barter PJ, Celermajer DS. Consumption of saturated fat impairs the anti-inflammatory properties of high-density lipoproteins and endothelial function. J Am Coll Cardiol 2006;48:715-720.

138. Wong S, Nestel PJ. Eicosapentaenoic acid inhibits the secretion of triacylglycerol and of apoprotein B and the binding of LDL in Hep G2 cells. Atherosclerosis 1987; 64:139-146.

139. Denmacker PN, Reijnen IG, Katan MB, Stuyt PM, Stalenhoef AF. Increased removal of remnants of triglyceride-rich lipoproteins on a diet rich in polyunsaturated fatty acids. Eur J Clin Invest 1991;21:197-203.

140. Zheng C, Khoo C, Furtado J, lkewaki K, Sacks FM. Dietary monounsaturated fat activates metabolic pathways for triglyceride-rich lipoproteins that involve apolipoproteins E and C-III. Am J Clin Nutr 2008;88:272-281.

141. Chelland Campbell S, Moffatt RJ, Stamford BA. Smoking and smoking cessation - the relationship between cardiovascular disease and lipoprotein metabolism: a review. Atherosclerosis 2008;201:225-235.

142. Facchini FS, Hollenbeck CB, Jeppesen J, Chen YD, Reaven GM. Insulin resistance and cigarette smoking. Lancet 1992;339:1128-1130

143. The Look AHEAD Research Group. Reduction in weight and cardiovascular risk factors in individuals with type 2 diabetes. Diabetes Care 2007;30:1374-1383.

144. The Look AHEAD Research Group. Long-term effects of a lifestyle intervention on weight and cardiovascular risk factors in individuals with type 2 diabetes mellitus. Arch Intern Med 2010;170:1566-1575.

145. Ilanne-Parikka P, Eriksson JG, Lindström J, Peltonen M, Aunola S, Hämäläinen $\mathrm{H}$, Keinänen-Kiukaanniemi $S$, Laakso $M$, Valle TT, Lahtela J, Uusitupa $M$, Tuomilehto J, Finnish Diabetes Prevention Study Group. Effect of lifestyle intervention on the occurrence of metabolic syndrome and its components in the Finnish Diabetes Prevention Study. Diabetes Care 2008;31:805-807.

146. Uusitupa M, Peltonen M, Lindström J, Aunola S, llanne-Parikka $P$, Keinänen-Kiukaanniemi S, Valle TT, Eriksson JG, Tuomilehto J, Finnish Diabetes Prevention Study Group. Ten-year mortality and cardiovascular morbidity in the Finnish Diabetes Prevention Study - secondary analysis of the randomized trial. PLOS ONE 2009;4:e5656.

147. Sigal RJ, Kenny GP, Boulé NG, Wells GA, Prud'homme D, Fortier M, Reid RD, Tulloch H, Coyle D, Phillips P, Jennings A, Jaffey J. Effects of aerobic training, resistance training, or both on glycemic control in type 2 diabetes: a randomized trial. Ann Intern Med 2007;147:357-369. 
148. Jeon CY, Lokken RP, Hu FB, Van Dam RM. Physical activity of moderate intensity and risk of type 2 diabetes. A systematic review. Diabetes Care 2007;30:744-752.

149. Schuler G, Hambrecht R, Schlierf G, Niebauer J, Hauer K, Neumann J, Hoberg E, Drinkmann A, Bacher F, Grunze M. Regular physical exercise and low-fat diet. Effects on progression of coronary artery disease. Circulation 1992;86:1-11.

150. Watts GF, Lewis B, Brunt JN, Lewis ES, Coltart DJ, Smith LD, Mann JI, Swan AV. Effects on coronary artery disease of lipid-lowering diet, or diet plus cholestyramine, in the St Thomas' Atherosclerosis Regression Study (STARS). Lancet 1992;339:563-569.

151. Ornish D, Brown SE, Scherwitz LW, Billings JH, Armstrong WT, Ports TA, McLanahan SM, Kirkeeide RL, Brand RJ, Gould KL. Can lifestyle changes reverse coronary heart disease? The Lifestyle Heart Trial. Lancet 1990;336: 129-133.

152. Hjermann I, Velve Byre K, Holme I, Leren P. Effect of diet and smoking intervention on the incidence of coronary heart disease. Report from the Oslo Study Group of a randomised trial in healthy men. Lancet 1981;2:1303-1310.

153. Burr ML, Fehily AM, Gilbert JF, Rogers S, Holliday RM, Sweetnam PM, Elwood PC, Deadman NM. Effects of changes in fat, fish, and fibre intakes on death and myocardial reinfarction: diet and reinfarction trial (DART). Lancet 1989;2:757-761.

154. de Lorgeril M, Renaud S, Mamelle N, Salen P, Martin JL, Monjaud I, Guidollet J, Touboul P, Delaye J. Mediterranean alpha-linolenic acid-rich diet in secondary prevention of coronary heart disease. Lancet 1994;343:1454-1459.

155. Brown BG, Stukovsky KH, Zhao XQ. Simultaneous low-density lipoprotein-C lowering and high-density lipoprotein- $\mathrm{C}$ elevation for optimum cardiovascular disease prevention with various drug classes, and their combinations: a meta-analysis of 23 randomized lipid trials. Curr Opin Lipidol 2006;17:631-636.

156. Chapman MJ, Redfern JS, McGovern ME, Giral P. Niacin and fibrates in atherogenic dyslipidemia: pharmacotherapy to reduce cardiovascular risk. Pharmacol Ther 2010;126:314-345.

157. Bays HE, Tighe AP, Sadovsky R, Davidson MH. Prescription omega-3 fatty acids and their lipid effects: physiologic mechanisms of action and clinical implications. Exp Rev Cardiovasc Ther 2008;6:391-409.

158. Kamanna VS, Kashyap ML. Mechanism of action of niacin. Am / Cardiol 2008;101: 20B-26B.

159. Gille A, Bodor ET, Ahmed K, Offermanns S. Nicotinic acid: pharmacological effects and mechanisms of action. Ann Rev Pharmacol Toxicol 2008;48:79-106.

160. Lamon-Fava S, Diffenderfer MR, Barrett PH, Buchsbaum A, Nyaku M, Horvath KV, Asztalos BF, Otokozawa S, Ai M, Matthan NR, Lichtenstein AH, Dolnikowski GG, Schaefer EJ. Extended-release niacin alters the metabolism of plasma apolipoprotein (Apo) A-I and ApoB-containing lipoproteins. Arterioscler Thromb Vasc Biol 2008;28:1672-1678.

161. Watts GF, Chan DC. Of mice and men: blowing away the cobwebs from the mechanism of action of niacin on HDL metabolism. Arterioscler Thromb Vasc Biol 2008;28:1892-1895.

162. Chan DC, Watts GF, Ooi EM, Ji J, Johnson AG, Barrett PH. Atorvastatin and fenofibrate have comparable effects on VLDL-apolipoprotein C-III kinetics in men with the metabolic syndrome. Arterioscler Thromb Vasc Biol 2008;28: $1831-1837$.

163. Watts GF, Barrett PH, Ji J, Serone AP, Chan DC, Croft KD, Loehrer F, Johnson AG. Differential regulation of lipoprotein kinetics by atorvastatin and fenofibrate in subjects with the metabolic syndrome. Diabetes 2003;52:803-811.

164. Chan DC, Watts GF, Ooi EM, Rye KA, Ji J, Johnson AG, Barrett PH. Regulatory effects of fenofibrate and atorvastatin on lipoprotein A-I and lipoprotein A-I:A-II kinetics in the metabolic syndrome. Diabetes Care 2009;32:2111-2113.

165. Guerin M, Bruckert E, Dolphin PJ, Turpin G, Chapman MJ. Fenofibrate reduces plasma cholesteryl ester transfer from HDL to VLDL and normalizes the atherogenic, dense LDL profile in combined hyperlipidemia. Arterioscler Thromb Vasc Biol 1996;16:763-772.

166. Chapman MJ, Le Goff W, Guerin M, Kontush A. Cholesteryl ester transfer protein: at the heart of the action of lipid-modulating therapy with statins, fibrates, niacin, and cholesteryl ester transfer protein inhibitors. Eur Heart J 2010;31:149-164.

167. Park Y, Harris WS. Omega-3 fatty acid supplementation accelerates chylomicron triglyceride clearance. J Lipid Res 2003;44:455-463.

168. Wang $\mathrm{H}$, Chen $\mathrm{X}$, Fisher EA. N-3 fatty acids stimulate intracellular degradation of apoprotein B in rat hepatocytes. J Clin Invest 1993;91:1380-1389.

169. Nestel PJ, Connor WE, Reardon MF, Connor S, Wong S, Boston R. Suppression by diets rich in fish oil of very low density lipoprotein production in man. J Clin Invest 1984;74:82-89.

170. Chan DC, Watts GF, Nguyen MN, Barrett PH. Factorial study of the effect of n-3 fatty acid supplementation and atorvastatin on the kinetics of HDL apolipoproteins A-I and A-II in men with abdominal obesity. Am J Clin Nutr 2006;84:37-43.

171. Sorrentino SA, Besler C, Rohrer L, Meyer M, Heinrich K, Bahlmann FH, Mueller M, Horváth T, Doerries C, Heinemann M, Flemmer S, Markowski A,
Manes C, Bahr MJ, Haller H, von Eckardstein A, Drexler H, Landmesser U. Endothelial-vasoprotective effects of high-density lipoprotein are impaired in patients with type 2 diabetes mellitus but are improved after extended-release niacin therapy. Circulation 2010;121:110-122.

172. Wu BJ, Yan L, Charlton F, Witting P, Barter PJ, Rye KA. Evidence that niacin inhibits acute vascular inflammation and improves endothelial dysfunction independent of changes in plasma lipids. Arterioscler Thromb Vasc Biol 2010;30:968-975.

173. Yvan-Charvet L, Kling J, Pagler T, Li H, Hubbard B, Fisher T, Sparrow CP, Taggart AK, Tall AR. Cholesterol efflux potential and antiinflammatory properties of high-density lipoprotein after treatment with niacin or anacetrapib. Arterioscler Thromb Vasc Biol 2010;30:1430-1438.

174. Blankenhorn DH, Nessim SA, Johnson RL, Sanmarco ME, Azen SP, Cashin-Hemphill L. Beneficial effects of combined colestipol-niacin therapy on coronary atherosclerosis and coronary venous bypass grafts. JAMA 1987;257 3233-3240.

175. Brown G, Albers JJ, Fisher LD, Schaefer SM, Lin JT, Kaplan C, Zhao XQ, Bisson BD, Fitzpatrick VF, Dodge HT. Regression of coronary artery disease as a result of intensive lipid-lowering therapy in men with high levels of apolipoprotein B. N Engl J Med 1990;23:1289-1298.

176. Kane JP, Malloy MJ, Ports TA, Phillips NR, Diehl JC, Havel RJ. Regression of coronary atherosclerosis during treatment of familial hypercholesterolemia with combined drug regimens. JAMA 1990;264:3007-3012.

177. Brown BG, Zhao XQ, Chait A, Fisher LD, Cheung MC, Morse JS, Dowdy AA, Marino EK, Bolson EL, Alaupovic P, Frohlich J, Albers JJ. Simvastatin and niacin, antioxidant vitamins, or the combination for the prevention of coronary disease. N Engl J Med 2001;345:1583-1592.

178. Whitney EJ, Krasuski RA, Personius BE, Michalek JE, Maranian AM, Kolasa MW, Monick E, Brown BG, Gotto AM Jr. A randomized trial of a strategy for increasing high-density lipoprotein cholesterol levels: effects on progression of coronary heart disease and clinical events. Ann Intern Med 2005;142:95-104.

179. Taylor AJ, Sullenberger LE, Lee HJ, Lee JK, Grace KA. Arterial Biology for the Investigation of the Treatment Effects of Reducing Cholesterol (ARBITER) 2: a double-blind, placebo-controlled study of extended-release niacin on atherosclerosis progression in secondary prevention patients treated with statins. Circulation 2004;110:3512-3517.

180. Taylor AJ, Lee HJ, Sullenberger LE. The effect of 24 months of combination statin and extended-release niacin on carotid intima-media thickness: ARBITER 3. Curr Med Res Opin 2006;22:2243-2250.

181. Taylor AJ, Villines TC, Stanek EJ, Devine PJ, Griffen L, Miller M, Weissman NJ, Turco M. Extended-release niacin or ezetimibe and carotid intima-media thickness. N Engl J Med 2009;361:2113-2122.

182. Lee JM, Robson MD, Yu LM, Shirodaria CC, Cunnington C, Kylintireas I, Digby JE, Bannister T, Handa A, Wiesmann F, Durrington PN, Channon KM, Neubauer S, Choudhury R. Effects of high-dose modified-release nicotinic acid on atherosclerosis and vascular function: a randomized, placebo-controlled, magnetic resonance imaging study. J Am Coll Cardiol 2009;54:1787-1794.

183. The Coronary Drug Project Group. Clofibrate and niacin in coronary heart disease. JAMA 1975;231:360-381.

184. Canner PL, Berge KG, Wenger NK, Stamler J, Friedman L, Prineas RJ, Friedewald W. Fifteen year mortality in Coronary Drug Project patients: longterm benefit with niacin. J Am Coll Cardiol 1986;8:1245-1255.

185. Canner PL, Furberg CD, Terrin ML, McGovern ME. Benefits of niacin by glycemic status in patients with healed myocardial infarction (from the Coronary Drug Project). Am J Cardiol 2005;95:254-257.

186. Canner PL, Furberg CD, McGovern ME. Benefits of niacin in patients with versus without the metabolic syndrome and healed myocardial infarction (from the Coronary Drug Project). Am J Cardiol 2006;97:477-479.

187. Bruckert E, Labreuche J, Amarenco P. Meta-analysis of the effect of nicotinic acid alone or in combination on cardiovascular events and atherosclerosis. Atherosclerosis 2010;210:353-361.

188. Elam MB, Hunninghake DB, Davis KB, Garg R, Johnson C, Egan D, Kostis JB, Sheps DS, Brinton EA. Effect of niacin on lipid and lipoprotein levels and glycemic control in patients with diabetes and peripheral arterial disease: the ADMIT study: a randomized trial. Arterial Disease Multiple Intervention Trial. JAMA 2000;284:1263-1270.

189. Grundy SM, Vega GL, McGovern ME, Tulloch BR, Kendall DM, Fitz-Patrick D, Ganda OP, Rosenson RS, Buse JB, Robertson DD, Sheehan JP, Diabetes Multicenter Research Group. Efficacy, safety, and tolerability of once-daily niacin for the treatment of dyslipidemia associated with type 2 diabetes: results of the assessment of diabetes control and evaluation of the efficacy of niaspan trial. Arch Intern Med 2002;162:1568-1576.

190. McKenney JM, Jones PH, Bays HE, Knopp RH, Kashyap ML, Ruoff GE, McGovern ME. Comparative effects on lipid levels of combination therapy with a statin and extended-release niacin or ezetimibe versus a statin alone (the COMPELL study). Atherosclerosis 2007;192:432-437. 
191. Ballantyne CM, Davidson MH, McKenney J, Keller LH, Bajorunas DR, Karas RH. Comparison of the safety and efficacy of a combination tablet of niacin extended release and simvastatin vs simvastatin monotherapy in patients with increased non-HDL cholesterol (from the SEACOAST I study). Am J Cardiol 2008;101: 1428-1436.

192. Gleim G, Ballantyne CM, Liu N, Thompson-Bell S, McCrary Sisk C, Pasternak RC, Mitchel Y, Paolini JF. Efficacy and safety profile of co-administered ER niacin/laropiprant and simvastatin in dyslipidaemia. Br J Cardiol 2009;16: 90-97.

193. Lai E, De Lepeleire I, Crumley TM, Liu F, Wenning LA, Michiels N, Vets E, O'Neill G, Wagner JA, Gottesdiener K. Suppression of niacin-induced vasodilation with an antagonist to prostaglandin D2 receptor subtype1. Clin Pharmacol Ther 2007;81:49-57.

194. Shah S, Ceska IR, Gil-Extremera B, Paolini JF, Giezek H, Vandormael K, Mao A, McCrary Sisk C, Maccubbin D. Efficacy and safety of extended-release niacin/laropiprant plus statin vs. doubling the dose of statin in patients with primary hypercholesterolaemia or mixed dyslipidaemia. Int J Clin Pract 2010;64:727-738.

195. Maclean A, McKenney JM, Scott R, Brinton E, Bays H, Mitchel YB, Paoloni JF, Giezek H, Vandormael K, Ruck RA, Gibson K, McCrary Sisk C, Maccubbin DL. Efficacy and safety of extended-release niacin/laropiprant in patients with type 2 diabetes mellitus. Br J Cardiol 2011;18:37-45.

196. Ericsson CG, Hamsten A, Nilsson J, Grip L, Svane B, de Faire U. Angiographic assessment of effects of bezafibrate on progression of coronary artery disease in young male postinfarction patients. Lancet 1996;347:849-853.

197. Frick MH, Syvänne M, Nieminen MS, Kauma H, Majahalme S, Virtanen V, Kesäniemi YA, Pasternack A, Taskinen MR. Prevention of the angiographic progression of coronary and vein-graft atherosclerosis by gemfibrozil after coronary bypass surgery in men with low levels of HDL cholesterol. Lopid Coronary Angiography Trial (LOCAT) Study Group. Circulation 1997;96:2137-2143.

198. DAIS Investigators. Effect of fenofibrate on progression of coronary-artery disease in type 2 diabetes: the Diabetes Atherosclerosis Intervention Study, a randomised study. Lancet 2001;357:905-910.

199. Elkeles RS, Diamond JR, Poulter C, Dhanjil S, Nicolaides AN, Mahmood S, Richmond W, Mather H, Sharp P, Feher MD. Cardiovascular outcomes in type 2 diabetes. A double-blind placebo-controlled study of bezafibrate: the St. Mary's, Ealing, Northwick Park Diabetes Cardiovascular Disease Prevention (SENDCAP) Study. Diabetes Care 1998;21:641-648.

200. Zhu S, Su G, Meng QH. Inhibitory effects of micronized fenofibrate on carotid atherosclerosis in patients with essential hypertension. Clin Chem 2006;52: 2036-2042.

201. Hiukka A, Westerbacka J, Leinonen ES, Watanabe H, Wiklund O, Hulten LM, Salonen JT, Tuomainen TP, Yki-Järvinen H, Keech AC, Taskinen MR. Long-term effects of fenofibrate on carotid intima-media thickness and augmentation index in subjects with type 2 diabetes mellitus. J Am Coll Cardiol 2008;52:2190-2197.

202. Oliver MF, Heady JA, Morris J, Cooper J. A co-operative trial in the primary prevention of ischaemic heart disease using clofibrate. Report from the Committee of Principal Investigators. Br Heart J 1978;40:1069-1118.

203. Coronary Drug Project Research Group. Clofibrate and niacin in coronary heart disease. JAMA 1975;231:360-381.

204. Frick MH, Elo O, Haapa K, Heinonen OP, Heinsalmi P, Helo P, Huttunen JK, Kaitaniemi P, Koskinen P, Manninen V, Mäenpää H, Mälkönen M, Mänttäri M, Norola S, Pasternack A, Pikkarainen J, Romo M, Sjöblom T, Nikkilä EA. Helsinki Heart Study: primary-prevention trial with gemfibrozil in middle-aged men with dyslipidemia. Safety of treatment, changes in risk factors, and incidence of coronary heart disease. N Engl J Med 1987;317:1237-1245.

205. Rubins HB, Robins SJ, Collins D, Fye CL, Anderson JW, Elam MB, Faas FH, Linares E, Schaefer EJ, Schectman G, Wilt TJ, Wittes J. Gemfibrozil for the secondary prevention of coronary heart disease in men with low levels of highdensity lipoprotein cholesterol. Veterans Affairs High-Density Lipoprotein Cholesterol Intervention Trial Study Group. N Engl J Med 1999;341:410-418.

206. The BIP Study Group. Secondary prevention by raising HDL cholesterol and reducing triglycerides in patients with coronary artery disease. The Bezafibrate Infarction Prevention (BIP) Study. Circulation 2000;102:21-27.

207. Keech A, Simes RJ, Barter P, Best J, Scott R, Taskinen MR, Forder P, Pillai A, Davis T, Glasziou P, Drury P, Kesäniemi YA, Sullivan D, Hunt D, Colman P, d'Emden M, Whiting M, Ehnholm C, Laakso M, FIELD study investigators. Effects of long-term fenofibrate therapy on cardiovascular events in 9795 people with type 2 diabetes mellitus (the FIELD study): randomised controlled trial. Lancet 2005;366:1849-1861.

208. Jun M, Foote C, Lv J, Neal B, Patel A, Nicholls SJ, Grobbee DE, Cass A, Chalmers J, Perkovic V. Effects of fibrates on cardiovascular outcomes: a systemic review and meta-analysis. Lancet 2010;375:1875-1884.

209. Manninen V, Tenkanen L, Koskinen P, Huttunen JK, Mänttäri M, Heinonen OP, Frick $\mathrm{MH}$. Joint effects of serum triglyceride and LDL cholesterol and HDL cholesterol concentrations on coronary heart disease risk in the Helsinki Heart Study. Implications for treatment. Circulation 1992;85:37-45.

210. Robins SJ, Collins D, Wittes JT, Papademetriou V, Deedwania PC, Schaefer EJ, McNamara JR, Kashyap ML, Hershman JM, Wexler LF, Rubins HB, VA-HIT Study Group. Veterans Affairs High-Density Lipoprotein Intervention Trial. Relation of gemfibrozil treatment and lipid levels with major coronary events. JAMA 2001;285:1585-1591.

211. Sacks FM, Carey VJ, Fruchart JC. Combination lipid therapy in type 2 diabetes. $N$ Engl J Med 2010;363:692-694

212. Derosa G, Cicero AE, Bertone G, Piccinni MN, Ciccarelli L, Roggeri DE. Comparison of fluvastatin + fenofibrate combination therapy and fluvastatin monotherapy in the treatment of combined hyperlipidemia, type 2 diabetes mellitus, and coronary heart disease: a 12-month, randomized, double-blind, controlled trial. Clin Ther 2004;26:1599-1607.

213. Athyros VG, Papageorgiou AA, Athyrou VV, Demitriadis DS, Kontopoulos AG. Atorvastatin and micronized fenofibrate alone and in combination in type 2 diabetes with combined hyperlipidemia. Diabetes Care 2002;25:1198-1202.

214. Koh KK, Quon MJ, Han SH, Chung WJ, Ahn JY, Seo YH, Choi IS, Shin EK. Additive beneficial effects of fenofibrate combined with atorvastatin in the treatment of combined hyperlipidemia. J Am Coll Cardiol 2005;45:1649-1653.

215. Grundy SM, Vega GL, Yuan Z, Battisti WP, Brady WE, Palmisano J. Effectiveness and tolerability of simvastatin plus fenofibrate for combined hyperlipidemia (the SAFARI trial). Am J Cardiol 2005;95:462-468.

216. The ACCORD Study Group and ACCORD Eye Study Group. Effects of medical therapies on retinopathy progression in type 2 diabetes. New Engl J Med 2010; 363:233-244.

217. Keech AC, Mitchell P, Summanen PA, O'Day J, Davis TM, Moffitt MS, Taskinen MR, Simes RJ, Tse D, Williamson E, Merrifield A, Laatikainen LT, d'Emden MC, Crimet DC, O'Connell RL, Colman PG, FIELD study investigators. Effect of fenofibrate on the need for laser treatment for diabetic retinopathy (FIELD study): a randomised controlled trial. Lancet 2007;370:1687-1697.

218. Davidson MH, Armani A, McKenney JM, Jacobson TA. Safety considerations with fibrate therapy. Am J Cardiol 2007;99(suppl):3C-18C.

219. Health Sciences Authority. Increased myopathy with combination use of ER niacin/laropiprant (Tredaptive ${ }^{\circledR}$ ) and simvastatin $40 \mathrm{mg}$ in Chinese patients. Results from interim analysis of HPS2-THRIVE study. http://www.hsa.gov.sg/ publish/hsaportal/en/health_products_regulation/safety_information/product_ safety_alerts/safety_alerts_2010/increased_myopathy.html (21 January 2011).

220. Davis TM, Ting R, Best JD, Donoghoe MW, Drury PL, Sullivan DR, Jenkins AJ, O'Connell RL, Whiting MJ, Glasziou PP, Simes RJ, Kesäniemi YA, Gebski VJ, Scott RS, Keech AC, on behalf of the FIELD Study investigators. Effects of fenofibrate on renal function in patients with type 2 diabetes mellitus: the Fenofibrate Intervention and Event Lowering in Diabetes (FIELD) Study. Diabetologia 2011; 54:280-290.

221. Forsblom C, Hiukka A, Leinonen ES, Sundvall J, Groop PH, Taskinen MR. Effects of long-term fenofibrate treatment on markers of renal function in type 2 diabetes: the FIELD Helsinki substudy. Diabetes Care 2010;33:215-220.

222. Taskinen MR, Sullivan DR, Ehnholm C, Whiting M, Zannino D, Simes RJ, Keech AC, Barter PJ, FIELD study investigators. Relationships of HDL cholesterol, ApoA-I, and ApoA-II with homocysteine and creatinine in patients with type 2 diabetes treated with fenofibrate. Arterioscler Thromb Vasc Biol 2009;29: 950-955

223. Dietary supplementation with n-3 polyunsaturated fatty acids and vitamin $E$ after myocardial infarction: results of the GISSI-Prevenzione trial. Gruppo Italiano per lo Studio della Sopravvivenza nell'Infarto miocardico. Lancet 1999;354:447-455.

224. Yokoyama M, Origasa H, Matsuzaki M, Matsuzawa Y, Saito Y, Ishikawa Y, Oikawa S, Sasaki J, Hishida H, Itakura H, Kita T, Kitabatake A, Nakaya N, Sakata T, Shimada K, Shirato K, Japan EPA lipid intervention study (JELIS) Investigators. Effects of eicosapentaenoic acid on major coronary events in hypercholesterolaemic patients (JELIS): a randomised open-label, blinded endpoint analysis. Lancet 2007;369:1090-1098.

225. Kromhout D, Giltay EJ, Geleijnse JM; for the Alpha Omega Trial Group. n-3 Fatty acids and cardiovascular events after myocardial infarction. N Engl J Med 2010;363:2015-2026.

226. Leaf A. Omega-3 fatty acids and prevention of arrhythmias. Curr Opin Lipidol 2007; 18:31-34

227. Holman RR, Paul S, Farmer A, Tucker L, Stratton IM, Neil HAW, on behalf of the AFORRD Study Group. Atorvastatin in Factorial with Omega-3 EE90 Risk Reduction in Diabetes (AFORRD): a randomized controlled trial. Diabetologia 2009;52:50-59.

228. Grover SA, Kaouache M, Joseph L, Barter P, Davignon J. Evaluating the incremental benefits of raising high-density lipoprotein cholesterol levels during lipid therapy after adjustment for the reductions in other blood lipid levels. Arch Intern Med 2009:169:1-7. 
229. Robinson JG. Dalcetrapib: a review of Phase II data. Expert Opin Investig Drugs 2010;19:795-805.

230. Barter PJ, Caulfield M, Eriksson M, Grundy SM, Kastelein JJP, Komajda M, Lopez-Sendon J, Mosca L, Tardif J-C, Waters DD, Shear CL, Revkin JH, Buhr KA, Fisher MR, Tall AR, Brewer HB. Effects of torcetrapib in patients at high risk for coronary events. N Engl J Med 2007;357:2109-2122.

231. Hu X, Dietz JD, Xia C, Knight DR, Loging WT, Smith AH, Yuan H, Perry DA, Keiser J. Torcetrapib induces aldosterone and cortisol production by an intracellular calcium-mediated mechanism independently of cholesteryl ester transfer protein inhibition. Endocrinology 2009;150:2211-2219.

232. Forrest MJ, Bloomfield D, Briscoe RJ, Brown PN, Cumiskey AM, Ehrhart J, Hershey JC, Keller WJ, Ma X, McPherson HE, Messina E, Peterson LB, Sharif-Rodriguez W, Siegl PK, Sinclair PJ, Sparrow CP, Stevenson AS, Sun SY, Tsai C, Vargas H, Walker M 3rd, West SH, White V, Woltmann RF. Torcetrapib-induced blood pressure elevation is independent of CETP inhibition and is accompanied by increased circulating levels of aldosterone. $\mathrm{Br}$ J Pharmacol 2008;154:1465-1473.

233. Catalano G, Julia Z, Frisdal E, Vedie B, Fournier N, Le Goff W, Chapman MJ, Guerin M. Torcetrapib differentially modulates the biological activities of HDL2 and HDL3 particles in the reverse cholesterol transport pathway. Arterioscler Thromb Vasc Biol 2009;29:268-275.
234. Yvan-Charvet L, Matsuura F, Wang N, Bamberger MJ, Nguyen T, Rinninger F, jiang XC, Shear CL, Tall AR. Inhibition of cholesteryl ester transfer protein by torcetrapib modestly increases macrophage cholesterol efflux to HDL. Arterioscler Thromb Vasc Biol 2007;27:1132-1138.

235. Stein EA, Roth EM, Rhyne JM, Burgess T, Kallend D, Robinson JG. Safety and tolerability of dalcetrapib (RO4607381/JTT-705): results from a 48-week trial. Eur Heart J 2010;31:480-488.

236. Cannon CP, Shah S, Dansky HM, Davidson M, Brinton EA, Gotto AM, Stepanavage M, Liu SX, Gibbons P, Ashraf TB, Zafarino J, Mitchel Y, Barter P, the DEFINE Investigators. Safety of anacetrapib in patients with or at high risk for coronary heart disease. N Engl J Med 2010;363:2406-2415.

237. Nordestgaard BG. Does elevated C-reactive protein cause human atherothrombosis? Novel insights from genetics, intervention trials, and elsewhere. Curr Opin Lipidol 2009;20:393-401.

238. Frikke-Schmidt R. Genetic variation in the ABCA1 gene, HDL cholesterol, and risk of ischemic heart disease in the general population. Atherosclerosis 2010; 208:305-316.

239. Reiner Ž. Combined therapy in the treatment of dyslipidemia. Fundam Clin Pharmacol 2010;24:19-28.

240. Kontos MC, Joyner SE, Roberts CS, Anderson FP, Ornato JP, Tatum JL, Jesse RL. Implication of the new low-density lipoprotein goals in dyslipidemia management of patients with acute coronary syndrome. Mayo Clin Proc 2007;82:551-555. 